\title{
QUALITY OVER QUANTITY: REEXAMINING THE LINK BETWEEN ENTREPRENEURSHIP AND JOB CREATION
}

\author{
ADAM SETH LITWIN AND PHILLIP H. PHAN*
}

\begin{abstract}
Although much has been written about the quantity of jobs created by entrepreneurs, scholars have yet to examine the quality of these jobs. In this article, the authors begin to address this important issue by examining nearly 5,000 businesses that began operations in 2004 . They investigate the extent to which nascent employers provide what many think of as quality jobs-those offering health care coverage and a retirement plan. The authors find that because of small scale, constrained resources, and protection from institutional pressures, start-up companies do not provide their employees with either of these proxies for job quality, and their likelihood of offering health or retirement benefits increases only marginally over their first six years of operation. The finding that entrepreneurs' impressive record of job creation is not matched by a similarly impressive outcome with respect to job quality challenges policymakers to ensure that entrepreneurs are encouraged to create quality employment opportunities in the course of creating new businesses.
\end{abstract}

$\mathrm{F}$ ew challenge the conventional wisdom that small business is the chief engine of job creation in the United States. This belief becomes especially salient in media and policy circles during times of economic slowdown, fueling the prescription that fiscal measures should "prop up" small businesses. Researchers have largely corroborated this notion (Birch 1981, 1987; Neumark, Wall, and Zhang 2011), though recent analyses have shown that the job-creating properties typically ascribed to small businesses

\footnotetext{
*Adam Seth Litwin is Assistant Professor at the Carey Business School at Johns Hopkins University and a research affiliate of the Employment Policy Research Network. Phillip H. Phan is Professor at the Carey Business School at Johns Hopkins University. The authors acknowledge the diligent research assistance of Nicole Lott as well as the guidance of John C. Dencker, Joseph B. Farhat, E. J. Reedy, Alicia M. Robb, Sonali K. Shah, and Sheryl Winston Smith regarding the Kauffman Firm Survey. Early-stage suggestions from Matthew Bidwell and Forrest Briscoe as well as comments from Howard Aldrich, Jianxi Luo, and Joon Woo Sohn, seminar participants at the George Washington University, the Cornell University conference on job quality, the Kauffman Firm Survey Research Workshop, and the 2012 annual meetings of the Labor and Employment Relations Association and of the Industry Studies Association are acknowledged and appreciated. Special thanks to Carl Barsky and colleagues at the Bureau of Labor Statistics at the U.S. Department of Labor for its provision of unpublished data from the National Compensation Survey. Any opinions, findings, and conclusions expressed in the paper are those of the authors alone and do not necessarily reflect the opinions of the Ewing Marion Kauffman Foundation or the Bureau of Labor Statistics. Much of the data employed in this study are freely available from the Kauffman Foundation. For information regarding the computer programs used for this study, please address correspondence to the first author at aslitwin@jhu.edu.
} 
should actually be attributed to new businesses (Haltiwanger, Jarmin, and Miranda 2011). That is, entrepreneurs, in particular, deserve much if not all of the credit for job creation over the 25-year period beginning in 1980 (Haltiwanger, Jarmin, and Miranda 2009).

Although much has been written on the quantity of jobs created by new ventures, scholars have yet to examine the quality of these jobs. To date, the policy conversation has focused on ways the U.S. economy can respond to low-cost competition from overseas, by bolstering emerging "high-tech" industries like biotechnology or "green" energy or by reviving the nation's once-prospering manufacturing base, for example-both of which imply the promotion of entrepreneurship (Osterman and Shulman 2011). But, scholars have yet to answer a fundamental question about the quality of the jobs that could emerge from these or other policy choices: Are the jobs created by entrepreneurs "quality jobs," that is, sustainable employment relationships that truly improve the economic fortunes of their incumbents, their families, and by extension, the nation's overall economic well-being?

This article attempts to address this important issue. We draw on data from the Kauffman Firm Survey (KFS) to analyze the labor market behavior of nearly 5,000 businesses that began operations in 2004. The richness of these panel microdata allows us to examine the extent to which nascent employers provide what many think of as the bedrock of a "real job"health care coverage and a retirement plan (Kalleberg 2011: 123). We find support for theory linking the typical ascriptions of new businessessmall scale, constrained resources, and protection from institutional pressures-to the lack of health and pension benefits. More important, we find that the likelihood of start-ups offering health or retirement benefits increases only slightly over their first five to six years of operation. Scale appears to be the dominant driver of job quality for new businesses, as larger start-ups behave much like similarly sized established firms with respect to benefits.

Though our research is intended to establish only a baseline understanding of the quality of jobs created through entrepreneurship, the findings suggest the value of a nuanced approach to job creation policy. Aside from distilling the findings into policy and research implications, we offer some ideas for deepening the economic analysis of job quality determinants in new ventures.

\section{Entrepreneurship and Job Quality}

\section{Entrepreneurial Job Creation}

While one could argue that U.S. economic policy has sought to bolster domestic entrepreneurship since at least as far back as Alexander Hamilton's vision for a "modern economy," the current economic policy favoring small business began with Congress's passage of the Small Business Act of 1953. The law created the Small Business Administration (SBA), predicated on 
the notion that "small business is critical to our economic recovery and strength, to building America's future, and to helping the United States compete in today's global marketplace." 1

Interestingly, the foundation for a link between small business and job creation came more than a quarter century later with the work of David Birch $(1981,1987)$. His initial research, relying on data from the first half of the 1970s, underpinned his claim that two-thirds of all net new jobs were created by businesses with 20 or fewer employees, and that more than four out of five new jobs were created by businesses with 100 or fewer employees (1981). In a follow-up analysis of data from the period 1981 to 1985, he argued that the connection had grown stronger and that nearly $90 \%$ of employment growth over that period could be attributed to businesses with 20 or fewer employees (1987).

Though Birch's findings regarding size have drawn criticism (e.g., Davis, Haltiwanger, and Schuh 1996; Harrison 1997), they are routinely used to justify favorable regulation, tax incentives, and other government support for small businesses (Neumark et al. 2011). While improved data and techniques for analyzing them have tempered the magnitude of Birch's initial findings, it still appears that small firms and establishments create more jobs than do large businesses, and at least in the manufacturing and service sectors, establishment size is negatively associated with job creation (Neumark et al. 2011). Nonetheless, accepting the apparent correlation between establishment size and job creation, John Haltiwanger and colleagues (e.g., Davis et al. 1996; Haltiwanger et al. 2011) showed that the employment growth effects that had been attributed to size should more rightfully be attributed to the interaction of firm size and firm age, consistent with management studies linking new business formation to job creation (e.g., Dencker, Gruber, and Shah 2009). In fact, the analysis of John Haltiwanger, Ron Jarmin, and Javier Miranda (2009), based on very fine-grained data from the U.S. Census Bureau, concluded that excluding jobs from new ventures, the annual rate of employment growth between 1980 and 2005 would have been negative. Follow-up research illustrated that the best way to understand the relationship between entrepreneurship and employment growth was to think in terms of stocks and flows: while start-ups account for just $3 \%$ of total employment, they are responsible for the creation of one out of every five new jobs (2011).

\section{The Notion of Job Quality}

Even if one accepts the link between entrepreneurship and the quantity of jobs created, it does not necessarily follow that a policy-driven tide that boosts entrepreneurs' demand for labor necessarily lifts all boats. This disconnect results from the observation that not all jobs are created equal. Traditionally, a "job" meant one had entered into a permanent, long-term employment relationship, an exchange that essentially guaranteed a worker

${ }^{1}$ See http://www.sba.gov/content/mission-statement-0 (accessed October 1, 2011). 
access to health insurance and a pension or retirement plan ${ }^{2}$ (Kochan and Litwin 2011)-benefits that in other advanced industrial economies are typically borne by the state or guaranteed by regulation. Today, the word "job" need not conjure up notions of a "standard" employment relationship at all, as $30 \%$ of workers in the United States engage in "nonstandard" employment, which is inclusive of independent contractors, employment with contracting companies and temporary help agencies, part-time workers, and on-call/day workers (Kalleberg et al. 1997). Even when one is party to a conventional or standard employment relationship, to assume that it comes with health insurance and a retirement plan-the two benefits we use to assess "job quality"-is no longer safe. As we later explain in more detail, in the United States about $60 \%$ of employers offer their full-time employees some form of health care coverage, and fewer than half of all employers economy-wide offer their full-time workers any form of retirement plan (Bureau of Labor Statistics 2011).

Admittedly, one can imagine some businesses or even entire sectors offering psychologically rewarding work even if it does not come with health care coverage or employer-sponsored retirement plans. Furthermore, by focusing solely on employers, one is assuredly ignoring the supply-side, that is, worker-related, drivers of benefits. For instance, some workers may be willing to forego benefits, either because they prefer to self-insure (younger workers are more likely to fall into this category) and receive total compensation in cash or because they can access these benefits-health care, in particular-through a spouse or partner. Along the same lines, there could be unobserved differences in worker quality between businesses, so that the lack of benefits as a component of total compensation is not an indicator of poor job quality but of worker productivity. Though the potential biases arising from inattention to the supply side can and will be mitigated statistically, for example, by controlling for industry, we will return to this issue in our discussion of this study's limitations.

Having acknowledged the potential drawbacks to our approach, we can still substantiate our economic definition of job quality on a number of grounds. First, from a policy perspective, we know that workers in the United States obtain health insurance and retirement benefits primarily through employment (Kalleberg 2011), suggesting that workers in jobs without these benefits suffer from a depressed standard of living (Kalleberg and Van Buren 1996). Moreover, since our concern is with the low end of the quality spectrum, it makes sense for us to focus on what Frederick Herzberg's (1968 [2003]) classic treatment would label "hygiene factors"- those related to basic human and biological needs, namely survival, and not those that motivate people to grow and to achieve, which tend to be psychological in

\footnotetext{
${ }^{2}$ We use the word "pension" and the phrase "retirement plan" interchangeably. For this article, "pension" does not imply a traditional, defined-benefit plan, as it has come to be understood colloquially. Rather, a "pension" can be any sort of retirement plan-defined-benefit, defined-contribution, or a hybrid thereof.
} 
nature. Arguably, health and economic security are such hygiene factors. Second, from a statistical perspective, Arne Kalleberg and Mark Van Buren's (1996) empirical study revealed that health care coverage and pensions (along with some forms of paid leave) load onto a single theoretical construct or factor, whereas benefits for dependents (e.g., childcare assistance) and participatory benefits (e.g., flextime and profit-sharing) load onto separate factors that are not driven by the same determinants. Therefore, while narrow, our definition of job quality is theoretically conservative from the standpoint of the literature.

\section{Determinants of Job Quality}

If it were the case that new businesses create low-quality jobs, what would explain it? The key is to first identify the drivers of job quality likely to be absent in new firms. Then, show that these drivers explain variation in the quality of jobs created by entrepreneurs, and that those few new firms that do exhibit these features more typically associated with established firms, indeed, also offer jobs of high quality. Along these lines, received research leads us to focus on three factors likely to characterize most new businesses-scale diseconomies, resource constraints, and a relative lack of institutional pressures. We believe that each of these will deter entrepreneurs from offering high-quality jobs, but those few new businesses that manage to achieve scale economies, demonstrate resource slack, or are genuinely subject to institutional pressures to conform to employment practice norms will more likely go "against the grain" by offering health care benefits and pensions.

\section{Scale Diseconomies}

The size distribution of employers and the distribution of employment across these employers are well-known and largely uncontroversial features of the U.S. labor market. On the one hand, the size distribution of employers is radically skewed, with the vast number of businesses employing fewer than 20 people. On the other hand, just a handful of firms employ thousands of workers, but that handful is large enough such that these truly large workplaces account for more than half of all employment in the United States. ${ }^{3}$ Researchers typically consider the impact of workplace size on labor market outcomes against this backdrop. Therefore, although little or no research has been published on the quality of jobs created by new employers, just as in the case with the job creation literature, a fair bit of research exists on the quality of jobs in small firms relative to that in large firms. This literature can inform expectations regarding the link between entrepreneurship and job quality, as long as one is willing to accept that "small" often

\footnotetext{
${ }^{3}$ In 2008, 50.6\% of all paid employees in the United States worked for the $0.3 \%$ of enterprises that employed more than 500 employees (Bureau of the Census 2008).
} 
includes workplaces of 500 or more employees-easily many orders of magnitude greater than the 2 to 3 employee mean size for a brand new or emerging business. Nonetheless, whether based on data from individuals reporting access to benefits through their employers or data from employers reporting their offering of different sorts of benefits to their employees, received findings are conclusive and well-encapsulated in Charles Brown, James Hamilton, and James Medoff's (1990) extensive analysis. ${ }^{4}$ Their findings revealed that jobs created by small firms, relative to those created by large firms, offer less generous health care and retirement benefits. What is more, they showed that these missing fringe benefits are not compensated for with higher wages, better working conditions, or greater employer investments in training, as small employers score significantly lower on all of these dimensions as well.

A number of other large-sample studies have shown that large firms are more likely than small firms to provide benefits to their workers (e.g., Rebitzer 1986; Kalleberg and Van Buren 1996; Belman and Groshen 1998; Hollister 2004), namely health care coverage and pensions, and that the negative association between size and employee benefits is especially pronounced for those benefits that impose a direct cost on employers (Knoke 1994). In fact, Shelley MacDermid, Leon Litchfield, and Marcie PittCatsouphes (1999) showed that larger companies are more apt to offer all but one of 22 benefits asked about on their survey, the one exception being on-the-job training.

Distinguishing size from life cycle stage is critically important-"smallness" from "newness" (Edwards and Ram 2010) - yet, the fact is that virtually all emerging firms are small at inception (Cardon and Stevens 2004). Therefore, we can begin theorizing on the drivers of job quality in emerging ventures by considering the impact of scale, in particular, actual scale economies (or diseconomies) in production. As noted above, much of the received theory in this vein focuses on compensation, namely wages, and attempts to explain why large firms would pay more than small ones. This notion can be adapted to explain why small firms would be less apt to offer high-quality jobs.

First, it is certainly the case that larger firms are characterized by greater capital intensity, leading some to argue, the direct effect of which is to make job vacancies—which make for idling capital—more costly (Oi 1983; Idson and Feaster 1990). Along with high capital intensity comes production processes that are highly interdependent in nature (Griliches 1969; Rebitzer and Taylor 1995), requiring that workers be especially dependable and disciplined, since one unproductive worker can be enough to reduce productivity across the line. Similarly, large-scale operations create managerial

${ }^{4}$ While 500 employees may seem like a high cutoff point for defining a "small business," such a threshold is commonly used. The SBA, for example, specifies its size thresholds by industry, ranging from as low as 100 workers for wholesale trade to 1,500 for petroleum refineries and telecommunications. Nonetheless, Brown, Hamilton, and Medoff's (1990) conclusions were not sensitive to their specific choice of threshold. 
challenges for monitoring and supervising workers, prompting employers to boost remuneration as a "carrot" to prevent shirking (Oi 1983; Rebitzer 1993; Fairris and Alston 1994). Conversely, one would expect that newer firms, to the extent they are characterized by lower capital intensity, and therefore, more segmented or disjointed production processes and certainly greater ease of monitoring and supervision, are less likely to feel the need to offer their workers a generous package of fringe benefits.

A separate line of thinking with respect to scale diseconomies comes from dual labor market theory (Doeringer and Piore 1971; Piore 1973). This approach suggests that new firms, particularly to the extent they are small, have less scope for long-term attachment to employees (Reilly 1995). In the case of small firms, this could be because they lack internal labor markets (ILMs), and thus, opportunities for advancement (Hollister 2004). This fact makes it especially unlikely that an employer would invest in benefits with high, upfront costs and more distant, long-term benefits (Cardon and Stevens 2004). ${ }^{5}$

At least two other arguments can be made for the relationship between scale economies and job quality. First, larger employers are likely to have more bargaining power vis-à-vis their vendors, enabling them to acquire production inputs-including benefits for their workforce-on a less expensive basis per employee. And, of course, having more employees across which to spread the fixed costs of initiating any particular benefit will also reduce the cost per employee (Sels et al. 2006a, 2006b).

In short, we expect the size of a new venture to be a positive predictor of whether it offers health care and retirement benefits, even after controlling for other determinants of job quality. Moreover, with all of the many ways that scale can drive job quality, we expect size to be the key variable distinguishing the behavior of these new employers from that of all employers across the economy.

Hypothesis 1a: The size of an emerging business will be positively associated with the probability that it offers its full-time employees a health insurance plan.

Hypothesis 1b: The size of an emerging business will be positively associated with the probability that it offers its full-time employees a retirement plan.

\section{Constrained Resources}

Closely related to scale economies in production, the degree of resource slack characterizing an entrepreneurial business can also impact the quality of the jobs it creates. While the notion of "slack" goes at least as far back as Chester Barnard (1938), James March and Herbert Simon (1958) were the

\footnotetext{
${ }^{5}$ Interestingly, in her attempt to disentangle the drivers of the firm-size wage effect (FSWE), Hollister (2004) found the most support for the ILM argument, in particular, since changes in the FSWE appear to co-vary with a decline in her measure of ILM incidence.
} 
first to use the term explicitly in the organizational context (Tan and Peng 2003). Today, the most commonly used definition of the general slack construct comes from Bourgeois (1981: 29), who claimed that "slack" "conveys the notion of a cushion of excess resources available in an organization that will either solve many organizational problems or facilitate the pursuit of goals outside the realm of those dictated by optimization principles."

Many others have since advanced the concept by identifying different forms of slack, generally in an effort to demonstrate differences in antecedents (e.g., Sharfman, Wolf, Chase, and Tansik 1988), or the differential impact of resource slack on strategic exploration or exploitation (Voss, Sirdeshmukh, and Voss 2008) or other types of organizational behaviors (Thompson 1967). The specific form of slack that we consider here is what the literature labels "financial" (e.g., Voss et al. 2008), "unabsorbed" (e.g., Singh 1986; Nohria and Gulati 1996), or "high-discretion" slack (e.g., Sharfman et al. 1988). In short, we are referring to liquid, often cash or cash-equivalent, resources that owners or managers have at their disposal for responding to competitive pressures. And, we expect that new businesses are unlikely to exhibit an excess of such resources.

This phenomenon has been labeled "resource poverty" (Welsh and White 1981). In particular, an emerging business's dependence on start-up capital makes it less likely to have retained earnings or other cash reserves from which to finance those employee benefits requiring upfront costs, such as the payment of health care premiums or the establishment of retirement benefit accounts (Cardon and Stevens 2004). As William Dennis (2000: 253) stated, "New businesses ... usually need all the capital their owners can raise to finance their ventures and have little to spare for expenditures like health insurance or pensions." In sum, as was the case with scale, we expect that new employers are at a disadvantage relative to more established ones with respect to resource slack. Therefore, those few entrepreneurs who manage to accumulate resources should be more likely to offer jobs of high quality.

Hypothesis 2a: The degree of resource slack in an emerging business will be positively associated with the probability that it offers its full-time employees a health insurance plan.

Hypothesis 2b: The degree of resource slack in an emerging business will be positively associated with the probability that it offers its full-time employees a retirement plan.

\section{Lack of Institutional Pressures}

The pressures of institutionalization (Meyer and Rowan 1977; DiMaggio and Powell 1983) serve as a final prod for employers to offer quality jobs. Indeed, the degree of institutional pressure felt by a new business is likely to be low for a number of reasons. First, small firms are much less likely to be shaped by their national environments than are otherwise similar larger firms (Wever 1995; Edwards and Ram 2010). That is, the corner "mom and 
pop" is less likely to be picketed for the treatment of its employees than is the local Walmart. Therefore, to the extent that providing high-quality jobs to full-time employees is still a norm, which likely differs substantially by industry, newer and smaller employers would feel less pressure to comply. Second, new businesses, again, largely pursuant to their small size, tend to be less visible to and therefore receive less attention from regulators, the media, and the public (Powell 1991; Goodstein 1994). Similarly, to the extent new ventures are less likely to appear on the "radar screen" of labor organizers, they are less likely to be unionization targets, attenuating the institutional pressures that have long been shown to result from the threat of unionization (Slichter, Healy, and Livernash 1960; Leicht 1989; Western and Rosenfeld 2011).

Even within a sample limited to new businesses, at least two sources of variation occur in the degree to which organizations are subject to normative pressures. First, public policy in the United States favors the employment relationship as the primary conduit for health care coverage and retirement benefits. Therefore, those emerging businesses that serve local, state, and federal governments, and so consequently are more likely to be visible to these regulatory bodies (Baron et al. 1986; Ingram and Simons 1995) — not to mention to their respective communities-would be more likely to comply with the normative pressure to promote social welfare by providing jobs of high quality (Oliver 1991; Osterman and Shulman 2011). Second, over time, young firms must find ways to gain legitimacy in the eyes of trading partners, potential employees, regulators, and customers, and must do so on a relatively thin record of experience and performance (Hannan and Freeman 1984; Cardon and Stevens 2004). As a result, those fledgling businesses that survive will be increasingly likely to submit to institutional pressures, irrespective of size, in an effort to mimic successful, larger firms. ${ }^{6}$ This facilitates their gaining access to the employee base, customer base, and other resources necessary for continued growth (Wholey and Brittain 1986; Aldrich and Fiol 1994). As a result, one can construe time itself as a proxy for the extent to which institutional pressure bears down on new employers. The key point is that new businesses generally will not face institutional pressure to the same degree as do established businesses. Those that do will be more likely than otherwise similar businesses to offer health and pension plans to their employees.

Hypothesis 3a: The level of institutional pressure confronting an emerging business will be positively associated with the probability that it offers its full-time employees a health insurance plan.

\footnotetext{
${ }^{6}$ Haltiwanger, Lane, and Spletzer (2007) found that businesses come to resemble one another in their behavior as employers, in the sense that their pay and productivity and the skill composition of their respective workforces converge as new businesses survive and mature. Such mimicry is endemic to institutionalization processes.
} 
Hypothesis 3b: The level of institutional pressure confronting an emerging business will be positively associated with the probability that it offers its full-time employees a retirement plan.

\section{Data and Methods}

\section{The Kauffman Firm Survey}

Our analysis relies on the Kauffman Firm Survey (KFS), a panel of 4,928 businesses founded in 2004 and surveyed annually from 2005 to 2010 (i.e., six observations per business). Each year's survey is administered beginning in June of the following year (e.g., June of 2005 for the 2004 data). The KFS is designed and administered by the nonprofit Ewing Marion Kauffman Foundation with guidance from Mathematica Policy Research, Inc. Conducted by way of the Internet or by phone, the survey collects detailed data regarding the founding and the founders of the firm as well as financing methods, capital investments, and investments in intangible assets. It also canvasses for accounting data and information on intellectual property and business strategy, among other things. What makes it especially attractive for this study is the large number of very small businesses included in the sample, especially important for isolating the impact of scale at sizes far below the small business size thresholds in the extant literature. Also germane to this study is the rich set of items related to business organization and human resources (HR). In particular, surveyors ask a set of questions that allow researchers to construct measures not only of the size and composition of the workforce but of the nature of the employment benefits offered to workers. In particular, we can determine whether and when each nascent employer offers health insurance and retirement benefits.

Table 1 shows the industry breakdown of the founding cohort of businesses, both as an absolute number and as a percentage of the total initial sample. Owing to Kauffman's interest in innovation, the survey deliberately oversamples businesses in high-tech industries, using a stratified sampling methodology. This method has implications for our estimation strategy, to be explained below. The response rate for the initial survey round was $43 \%$, with rates significantly higher in subsequent years (e.g., $82 \%$ of those contributing data in the baseline year respond in year four). ${ }^{7}$

\section{Variables}

\section{Dependent Variables}

The dependent variables are described in the top panel of Table 2. In each survey round, respondents are asked, "As of December 31 [of last year], did [your business] offer full-time employees or owners a health insurance plan

\footnotetext{
${ }^{7}$ For more information on the KFS, see Robb et al. (2010).
} 
Table 1. Industry Composition of the Baseline Sample of Emerging Businesses

\begin{tabular}{lrc}
\hline Industry & $n$ & $\begin{array}{c}\text { Percentage of } \\
\text { initial sample (\%) }\end{array}$ \\
\hline Agriculture, Forestry, Fishing, and Hunting & 40 & 0.81 \\
Mining & 5 & 0.1 \\
Utilities & 6 & 0.12 \\
Construction & 390 & 7.91 \\
Manufacturing & 720 & 14.6 \\
Wholesale Trade & 219 & 4.44 \\
Retail Trade & 526 & 10.67 \\
Transportation and Warehousing & 112 & 2.27 \\
Information & 164 & 3.33 \\
Finance and Insurance & 186 & 3.77 \\
Real Estate and Rental and Leasing & 177 & 3.59 \\
Professional, Scientific, and Technical Services & 1,203 & 24.41 \\
Management of Companies and Enterprises & 10 & 0.2 \\
Administrative and Support and Waste Management & 360 & 7.31 \\
Educational Services & 29 & 0.59 \\
Health Care and Social Assistance & 121 & 2.46 \\
Arts, Entertainment, and Recreation & 105 & 2.13 \\
Accommodation and Food Services & 98 & 1.99 \\
Other Services (except Public Administration) & 454 & 9.21 \\
Public Administration & 3 & 0.06 \\
Total & 4,928 & $100^{*}$ \\
\hline
\end{tabular}

Source: Kauffman Firm Survey baseline year (2004), two-digit NAICS 2002, unweighted.

*The percentages may not sum to 100 due to rounding.

either through the business or an association?" Respondents answer this question "yes" or "no," and an affirmative answer is assigned the value of 1 while the negative becomes the referent category. The same question is posed and parameterized analogously for retirement benefits, that is, "a retirement plan such as profit sharing, pension, including $401 \mathrm{~K}$, annuity, Keogh, etc." These questions are not posed to those businesses that, in a given year, had a sole owner and no employees. This leads to a sizable number of missing observations-1,841 in the year of founding-though this number diminishes to below 750 for 2009, the last year for which we have data.

\section{Independent Variables}

Testing the hypotheses calls for measures of organizational scale, resources, and institutional pressures that could explain variation in the extent to which new employers proffer health and pension benefits. Information on how these variables, all of which are time-varying, are constructed appears in the bottom panel of Table 2. Hypotheses 1a and 1b, in particular, call for a size measure. While organizational size takes on a number of meanings and, therefore, should be operationalized differently in varying contexts (Kimberly 1976), Arne Kalleberg and Mark Van Buren (1996) argued that 
Table 2. Variable Definitions and Construction

\begin{tabular}{|c|c|c|}
\hline Variable & Definition/Survey item & Construction \\
\hline \multicolumn{3}{|l|}{ Dependent variables } \\
\hline Health care coverage & $\begin{array}{l}\text { "As of December } 31 \text { [of last year], did } \\
\text { [the business] offer full-time employ- } \\
\text { ees or owners a health insurance } \\
\text { plan either through the business or } \\
\text { an association?" }\end{array}$ & $\begin{array}{l}\text { Binary variable in which } 0=\text { "no" } \\
\text { and } 1=\text { "yes." }\end{array}$ \\
\hline Retirement plan & $\begin{array}{l}\text { "As of December } 31 \text { [of last year], did } \\
\text { [the business] offer full-time employ- } \\
\text { ees or owners a retirement plan such } \\
\text { as profit sharing, pension, including } \\
401(\mathrm{k}) \text {, annuity, Keogh, etc.?" }\end{array}$ & $\begin{array}{l}\text { Binary variable in which } 0=\text { "no" } \\
\text { and } 1=\text { "yes." }\end{array}$ \\
\hline \multicolumn{3}{|l|}{ Independent Variables } \\
\hline Number of employees & $\begin{array}{l}\text { "Not counting owner(s), on December } \\
31 \text { [of last year], how many people } \\
\text { worked for [the business]?" }\end{array}$ & $\begin{array}{l}\text { Continuous variable. Includes all } \\
\text { full-time and part-time employ- } \\
\text { ees, but excludes all contract } \\
\text { workers. }\end{array}$ \\
\hline Number of employees ${ }^{2}$ & $\begin{array}{l}\text { "Not counting owner(s), on December } \\
31 \text { [of last year], how many people } \\
\text { worked for [the business]?" }\end{array}$ & $\begin{array}{l}\text { Continuous variable. Squared } \\
\text { value of Number of employees. }\end{array}$ \\
\hline Profitable & $\begin{array}{l}\text { "What was [the business's] total profit } \\
\text { or loss for the [last] calendar year?" }\end{array}$ & $\begin{array}{l}\text { Binary variable set to } 1 \text { when prof- } \\
\text { its were positive. }\end{array}$ \\
\hline Competitive advantage & $\begin{array}{l}\text { "In [the survey year], did [the busi- } \\
\text { ness] have a competitive advantage } \\
\text { over its competitors?" }\end{array}$ & $\begin{array}{l}\text { Binary variable in which } 0=\text { "no" } \\
\text { and } 1=\text { "yes." }\end{array}$ \\
\hline Patents & $\begin{array}{l}\text { "Whether assigned by an owner or ob- } \\
\text { tained in some other way, does [the } \\
\text { business] have any patents?" }\end{array}$ & $\begin{array}{l}\text { Binary variable in which } 0=\text { "no" } \\
\text { and } 1=\text { "yes." }\end{array}$ \\
\hline Trademarks & $\begin{array}{l}\text { "Whether assigned by an owner or ob- } \\
\text { tained in some other way, does [the } \\
\text { business] have any trademarks?" }\end{array}$ & $\begin{array}{l}\text { Binary variable in which } 0=\text { "no" } \\
\text { and } 1=\text { "yes." }\end{array}$ \\
\hline $\begin{array}{l}\ln \text { (Government share } \\
\text { of total sales) }\end{array}$ & $\begin{array}{l}\text { "What percentage of the business's } \\
\text { sales were to government agencies?" }\end{array}$ & $\begin{array}{l}\text { Continuous variable, natural log } \\
\text { of percentage. }\end{array}$ \\
\hline Age & Linear time trend & $\begin{array}{l}\text { Discrete variable in domain }[0,5] \text {. } \\
\text { Set to } 0 \text { for the baseline year } \\
(2004) \text {, incrementing by } 1 \text { until } \\
\text { the final year of data }(2009) \text {. }\end{array}$ \\
\hline Age $^{2}$ & Quadratic time trend & $\begin{array}{l}\text { Discrete variable in domain } \\
{[0,25] . \text { Squared value of Age. }}\end{array}$ \\
\hline
\end{tabular}

Source: All variables constructed from the public-use version of the Kauffman Firm Survey.

the number of employees is the most relevant measure of size when studying HR issues. Technically, we also know that the number of employees is highly correlated with other facets of size, including assets, sales, profits, and output, so that it can be generalized to a broader discussion on scale. This line of reasoning is consistent with prior studies of job creation by entrepreneurs (e.g., Dencker et al. 2009) as well as received analyses of job quality (Hollister 2004). Therefore, we include a linear and quadratic measure of the number of employees, inclusive of full- and part-time employees, but excluding owners and contract workers.

Hypotheses 2a and 2b theorize a link between resource slack and the likelihood of a new employer offering health and retirement benefits. There 
has been no consensus as to the best ways to measure slack, though a number of scholars have suggested or relied on financially derived indicators (e.g., Nohria and Gulati 1996). Following Bourgeois's (1981) advice, and accepting the coarseness of the measures available to us, we attempt to measure slack in multiple ways, both objectively and subjectively. Indeed, new businesses can "show their cards" in a number of ways with respect to the forms of slack with which we are concerned. All of these are tantamount to the firm signaling in some way that it earns economic rents. Profitability, for example, is a straightforward financial signal that a firm has resources on hand to finance the provision of benefits-consistent with one classic definition of slack as the surplus of income over the costs of production (Cyert and March 1963). Therefore, following Dennis (2000), we capture whether the firm is profitable. We do so using a dummy variable equal to 1 in profitable business-years.

Strategic management theory dictates that firms must have a "strategic competitive advantage" if they are to generate sustained economic rents (Porter 1980). Coupled with the finding that competitive pressures decay with slack (Pfeffer and Leblebici 1973; Pfeffer 1978), one would expect that those few new businesses that achieve a strategic competitive advantage are better resourced, and therefore, more likely to provide jobs of high quality. Consequently, we include a dummy variable equal to 1 for those businesses claiming to have a strategic competitive advantage in the eyes of the ownerrespondent.

Finally, one might expect that the legally sanctioned market power that entrepreneurs and others can secure for their intellectual property might also afford them supernormal profits from which to finance the provision of higher quality jobs. Therefore, we include two binary terms to account for the economic rents that potentially arise from appropriating the returns to protected intellectual property. Specifically, we include a dummy variable equal to 1 for those businesses that claim to hold one or more patents and an analogous binary variable measuring the incidence of trademarks.

The third set of hypotheses theorized a link between institutional pressures and an entrepreneur's likelihood of offering health and retirement benefits. As argued above, the type of customers served by a business will influence the quality of its employment relationships. Specifically, those businesses serving public sector customers are more likely to experience the sorts of institutional pressures that encourage them to offer health and retirement benefits. Therefore, we measure the share of each company's sales attributable to government agencies. This measurement is made using a continuous variable, the natural log of the percentage of the business's sales that fall into that category; however, we would have been equally comfortable using any transformation that allows for an association that is monotonically increasing, albeit at a decreasing rate. ${ }^{8}$

\footnotetext{
${ }^{8}$ This required us to re-code the log zero-cases as zeros rather than leaving them as "undefined." Alternative ways of dealing with this issue, such as adding 1 to all observations to avoid zero-cases, yielded
} 
Aside from considering the government share of a business's receipts, we measure the age of a business. As argued above, conditional on its survival, age or vintage is one assessment of the extent to which the business is subjected to institutional pressures. There are, of course, countless ways to measure age, the most straightforward of which would be a simple, linear term. This measure, however, could be biased downward by the precipitous economic slowdown that began in 2008. Therefore, we also include a quadratic term to allow for curvilinearity in the relationship between age and job quality. The linear term begins at 0 for the year of founding with annual increments until the final year of data, when it takes on the value of 5 . Likewise, the quadratic term takes on values from 0 to $25 .{ }^{9}$

Lastly, some of the estimates will include a vector of binary variables to control for industry effects at the two-digit NAICS level. These pick up some of the general characteristics of labor and product markets within which entrepreneurs must operate, including product market concentration, capital intensity, and profitability (Kalleberg and Van Buren 1996; Holzer, Lane, Rosenblum, and Andersson 2011), particularly to the extent that these variables are neither observed directly at the employer level or are measured with error when using observable independent variables as proxies, for instance, scale as a measure of capital intensity. For example, if one believes the service sector is generally characterized by high competition in the product market and an oversupply of workers in the labor market, one would expect these forces, particularly in concert, to have a negative impact on observed job quality. Matissa Hollister (2004) also pointed out that industries face different production technologies, which could impact their decisions over offering certain benefits. Finally, as noted above, controlling for industry also mitigates any biases that might otherwise arise from our singular focus on the demand side of the employment equation.

\section{Methods}

Our estimates must predict the likelihood that a business offers its full-time employees health insurance and a retirement plan as a function of the business's scale and resources as well as of the institutional pressures the business faces. OLS proves insufficient for a number of reasons. To start, OLS yields predicted probabilities outside of the $[0,1]$ range as well as residuals of unequal variance (Aldrich and Nelson 1984), problems that are

similar results. Similarly, other transformations that allowed for a monotonically increasing relationship of diminishing magnitude, for example, the square root transformation and the inverse hyperbolic sine transformation, also yielded very comparable results.

${ }^{9}$ Of course, whether we iterate our age measure from 0 to 5 or from 1 to 6 makes no difference for multivariate estimation. Conceptually, since the businesses are founded in 2004, they are all less than one year old on December 31, 2004, the date at which job quality is first assessed. So, for analytical purposes, we regard the baseline year as the zero-year and the subsequent year as the first full year of operation. As a result, we are technically analyzing businesses over their first five to six years of operations, depending on precisely what date in 2004 they were founded. 
well-addressed by logistic or probit regression. Even a standard logit or probit, however, leaves two additional complications unresolved. First, the longitudinal nature of the data-up to six observations per business-calls for a technique that addresses the dependence structure of the data (Skrondal and Rabe-Hesketh 2004). At minimum, we could treat the clustering of cases as a "nuisance factor" by simply clustering our standard errors. The panel nature of the KFS though presents what should be considered more of an opportunity than a nuisance. That is, it allows us to take advantage of multilevel modeling techniques by estimating job quality over the first five to six years of a business's existence (Singer and Willett 2003), exploiting variation between businesses as well as variation within each business unit. ${ }^{10}$ Unfortunately, even this robust family of models leaves a critical concern unaddressed, which is the complex nature of the original sampling and subsequent, systematic sample attrition arising from the nonrandom failure of new ventures. Indeed, received research, including some using the KFS data, makes clear that new ventures face a high likelihood of failure (Stinchcombe 1965; Carroll and Hannan 2000; Smith 2011). Were the likelihood of a given employer's failure, and thus, subsequent disappearance from the data set not accounted for, any estimates run on the resulting unbalanced panel would likely suffer from so-called survival or attrition bias.

The literature on attrition bias in longitudinal surveys has long been available. In general, attrition is defined as the permanent loss of sample members from a longitudinal sample. It creates the threat of bias only if those units that drop out after the original sample are systematically different from those that remain in the sample throughout the observation period-six years in our case. If this occurs, the remaining sample, of course, represents a population different from the original sample (Cochran 1977). Without any correction, estimates would not generalize back to the original population of businesses, but rather, to the subpopulation of surviving businesses. Three common methods are available for addressing this statistical challenge (Farhat 2012). First, surveyors can attempt to track every single participant through repeated attempts to contact them, preventing attrition in the first place. Indeed, KFS surveyors do this. The issue of businesses truly disappearing is a rather minor one in this context, however, as just 147 of the 4,928 businesses (about 3\%) truly vanish from the data set without any explanation over the entire six years' worth of data collection. The real challenge arises from those businesses that surveyors are able to locate and include in the survey wave, but whose data are missing, because they have voluntarily or involuntarily ceased operations. By the sixth year of data, this number rises to 1,747 , or about $35 \%$ of the original sample of new businesses. This leaves

\footnotetext{
${ }^{10}$ Not surprisingly, more variation occurs between businesses than within them; nonetheless, plenty of within-business variation occurs as well. In the case of health insurance, $\sigma_{\text {between }}=.39$ and $\sigma_{\text {within }}=.24$. In the case of pensions, $\sigma_{\text {between }}=.28$ and $\sigma_{\text {within }}=.20$. Furthermore, using health insurance as an example, an examination of transition probabilities reveals that about $12 \%$ of those not offering the benefit in a given year will offer it the following year, and that about $16 \%$ of those offering it in a given year will not offer it the following year.
} 
two alternatives. One is to estimate a two-stage, sample selection model like that proposed by Heckman $(1976,1979)$ or, perhaps, a less-restrictive semiparametric alternative (Rosenbaum and Rubin 1983; Guo and Fraser 2010; Wooldridge 2010). Instead, one can use complex sample weighting to adjust for systematic sample attrition in each subsequent wave of the survey, whereby weights are recalculated and reassigned to each surviving sample unit in each subsequent round to ensure that each wave's resulting sample continues to represent the original population from which the original sample was drawn.

A number of reasons explain why we have opted to rely on weights (in addition to the surveyors' considerable efforts to track participants) rather than on sample selection models. First, the effective use of a sample selection model requires, among other things, the identification of at least one variable that drives firm survival ("relevance") without having any systematic relationship with the dependent variables of interest ("exogeneity") (Reiss 2011), a condition that is generally difficult to substantiate in practice (Wooldridge 2010). Second, in those rare situations in which survey designers foresaw the survival issue at the time of survey design, as in the case of the KFS, estimates that rely on weighting and re-weighting with each subsequent survey wave perform better than two-stage estimates on unweighted data (McGuigan, Ellickson, Hays, and Bell 1997; Farhat 2012). This results because the weights map the sample in each follow-up survey back to represent the original sample from the baseline year. In the baseline year itself, weights are developed to account for unequal sampling probabilities that arise from intentional oversampling of some businesses and undersampling of others, that is, sample selection bias. Then, with each subsequent administration of the survey, weights are first adjusted to compensate for nonresponse, meaning attrition, and adjusted once more to ensure the surviving population represents the original population. This suggests that by relying on probability weights, we are not only addressing survival bias. In addition to ensuring that our estimates generalize back to the original sample of businesses, the weights ensure that estimates pertaining to the original sample-which strategically oversampled some firms and undersampled others-also generalize to the intended original population of new businesses. Even if we were only examining the original cross section of firms, we would want to use survey weights to ensure generalizability to the entire universe of new ventures in 2004. Therefore, relying on weights works to address sampling bias as well as the larger challenge arising from survival bias. Finally, incorporating survey design features also enables us to partially relax the usual assumption of conditional independence across all observations, noted above, which would otherwise have to be done by estimating a multilevel model and/or clustered standard errors (Skrondal and Rabe-Hesketh 2004). The upshot is that we essentially estimate two separate, straightforward logit models-one for health insurance and another for pensions. These models rely on the probability weights that have been constructed by the surveyors to account both for sampling and for response bias in the 
Table 3. Means, Standard Deviations, and Correlations for Study Sample of Emerging Businesses

\begin{tabular}{lrrrrrrrrrr}
\hline Variable & Mean & \multicolumn{1}{c}{$S D$} & 1 & 2 & 3 & 4 & 5 & 6 & 7 & 8 \\
\hline 1 Health care coverage & .31 & .46 & 1.00 & & & & & & & \\
2 Retirement plan & .15 & .36 & .40 & 1.00 & & & & & & \\
3 Number of employees & 2.27 & 4.83 & .38 & .30 & 1.00 & & & & & \\
4 Profitable & .45 & .50 & .10 & .11 & .04 & 1.00 & & & & \\
5 Competitive advantage & .62 & .49 & .10 & .06 & .10 & .04 & 1.00 & & & \\
6 Patents & .03 & .17 & .09 & .07 & .08 & -.09 & .12 & 1.00 & & \\
7 Trademarks & .10 & .30 & .10 & .07 & .13 & .07 & .16 & .26 & 1.00 & \\
8 Government share of total sales & 6.83 & 20.49 & .10 & .13 & .07 & .08 & .02 & .05 & -.01 & 1.00 \\
9 Age & 2.41 & 1.74 & .09 & .12 & .11 & .11 & -.09 & .01 & -.02 & .08 \\
\hline
\end{tabular}

Source: Kauffman Firm Survey, all years, unweighted.

baseline survey and re-constructed with each survey wave to account for the systematic failure of new businesses, and thus, their permanent exit from the data set. ${ }^{11}$

\section{Results}

Table 3 provides means, standard deviations, and pair-wise correlations for the variables called on in the subsequent analyses. Note that less than onethird of the establishments (i.e., establishment-years) in the sample-31\%offer any form of health insurance to their full-time employees. About half as many businesses-15\%-offer some form of a pension or retirement plan. Businesses in the sample are quite small, employing about 2.3 workers, on average, which is consistent with an almost axiomatic notion motivating this analysis. That is, new employers are likely to have small-scale operations, highlighting the need to isolate the impact of smallness from that of newness. Furthermore, that the standard deviation of size is more than twice the mean highlights the severe left skew of the variable. The four binary measures of resource slack offer a less clear picture of the degree to which these businesses are resource-constrained. Just $10 \%$ of the respondents reported that they own a trademark that can be leveraged for supernormal profits, and just 3\% hold at least one patent. More than two out of every five business-years in the sample were profitable ones, and more than $60 \%$ of respondents believe they hold a "strategic competitive advantage." Since surveyors actually define the phrase for respondents, entrepreneurs are clearly articulating that they believe they have unique, profit-making potential not afforded to their competitors.

With respect to institutional pressures, fewer than $7 \%$ of receipts come from public sector customers, though the large standard deviation suggests it could be a substantial share of receipts for some businesses in the sample. It also reveals the left skew of its distribution, much as in the case of size, as

\footnotetext{
${ }^{11}$ While we have gone to great lengths to mitigate biases resulting from sampling and survival, our results are robust to methods that ignore sampling issues altogether.
} 
Table 4. Mean Values of Explanatory Variables

by Job Quality Status for the Baseline Sample of Emerging Businesses in the Year of Founding

\begin{tabular}{|c|c|c|c|c|c|c|}
\hline \multirow[b]{2}{*}{$\underline{\text { Variable }}$} & \multicolumn{3}{|c|}{ Health care } & \multicolumn{3}{|c|}{ Retirement } \\
\hline & No & Yes & $\mathrm{t}$-test & No & Yes & $\mathrm{t}$-test \\
\hline Number of employees & 1.77 & 5.36 & $(-20.00)^{* * *}$ & 2.34 & 6.07 & $(-12.94) * * *$ \\
\hline Profitable & .41 & .51 & $(-4.84)^{* * *}$ & .42 & .57 & $(-4.48) * * *$ \\
\hline Competitive advantage & .66 & .75 & $(-4.65) * * *$ & .68 & .74 & $(-2.13)^{*}$ \\
\hline Patents & .04 & .07 & $(-3.18) * * *$ & .05 & .07 & $(-1.73) *$ \\
\hline Trademarks & .14 & .23 & $(-5.86) * * *$ & .16 & .24 & $(-3.49) * * *$ \\
\hline Government share of total sales & 4.38 & 6.50 & $(-2.81) * *$ & 4.31 & 11.21 & $(-5.94)^{* * *}$ \\
\hline
\end{tabular}

Source: Kauffman Firm Survey baseline year (2004), unweighted.

$* p<.05, * * p<.01, * * * p<.001$, two-tailed test.

most businesses attribute no business at all to public sector customers. This suggests that on average, these businesses are not subject to much normative pressure from customers. The mean value for the time trend, 2.41 on a 0 to 5 scale, implies fewer observations at the end of the six-year observation period than there were at the beginning. Inferring anything from this mean measure alone is difficult, other than the fact that businesses often fail and subsequently exit the sample. As noted earlier, this inference is consistent with the high failure rate of new ventures (Carroll and Hannan 2000; Smith 2011), and the multivariate analyses account for the potential attrition bias that might otherwise result from this phenomenon. Finally, none of the variables in the study are strongly correlated with one another. The two dependent variables appear to co-vary, and size is positively pair-wise correlated with both of the benefits measures. There also appears to be a positive association between the two variables measuring the incidence of intellectual property.

Even in advance of the multivariate analysis, obvious patterns begin to emerge between each of the explanatory variables and the two measures of job quality. These patterns are illustrated in Table 4, which presents mean values for the independent variables in the year of founding-2004. Aside from looking only at the baseline sample, it calculates the observed sample means separately according to whether a business offers health insurance and whether it offers a pension plan. Note that all differences-in-means go in the hypothesized direction, and all are statistically significant, most at $p<.001$. Those new businesses offering health care report, on average, about 5.4 employees, whereas those who do not offer health insurance employ fewer than 2 workers. Similarly, those businesses offering a retirement plan in their year of founding have about 6 employees, on average, compared with 2.3 workers for those ventures not offering any form of retirement plan to their full-time staff. In our sample, profitable new businesses and those new businesses claiming to hold a competitive advantage are more likely to offer each of the two employee benefits used to assess job quality. In the case of profitability and pensions, the difference is 15 percentage points. 
Likewise, those businesses holding intellectual property in the form of patents and trademarks are more likely to offer both health and retirement benefits. And, there appears to be a link between the government share of a business's receipts and job quality. In the case of pensions, in particular, those businesses that did not offer a retirement plan credited about $4.3 \%$ of their sales to public sector customers, compared with an average of $11.2 \%$ for those businesses offering the benefit. ${ }^{12}$

In sum, it appears that size, resources, and one of our measures of institutional pressure are all positively associated with job quality, in accordance with the hypotheses. However, these are simply observed sample means for a single year. They do not test the hypotheses simultaneously nor do they allow us to follow businesses over time. While survival bias is not an issue when examining only the baseline sample-a single year's worth of datathese do not account for the complex design of the survey sample. And, of course, observed means are almost certainly, at least in part, a reflection of the industry composition of the baseline sample. We must wait until the multivariate analysis to tackle these issues.

Before turning to the multivariate analyses from which it will be either difficult or impossible to tease out interindustry effects, considering the differences in job quality between industries in the baseline sample is worthwhile. This step is facilitated by the calculation of benefits offer rates shown in Table 5. Keep in mind that in all cases, the cell sizes are smaller than those that appear in Table 1 because the strategic oversampling of high-tech industries implies the undersampling of others. Furthermore, as noted earlier, benefits incidence is never canvassed for those firms that have just one owner and no employees, which account for $38 \%$ of the sample in the year of founding. Therefore, the industry-level characteristics must be taken with a grain of salt given some excessively small cell sizes.

With those caveats, we first notice a fair bit of interindustry variation in both measures of job quality. Excluding those industries with negligible cell counts, wholesale trade is the industry most likely to offer its full-time employees health insurance in the year of founding. It does so $31 \%$ of the time, the only industry to achieve the overall, multiyear sample average reported in Table 3. Not surprisingly, in economy-wide data, wholesale trade is also one of the better-paying of the industries at the two-digit level (Bureau of Economic Analysis 2011), suggesting that when the fixed cost of health care premiums make up a smaller share of total compensation, businesses are more likely to offer the benefit. What belies this inference, however, is accommodation and food services, which also happens to be the biggest creator of jobs in the data set (Stangler and Litan 2009). In economy-wide data, this industry pays its workers less than any other (Bureau of Economic Analysis 2011). Yet, it still offers its full-time workers health care coverage with .29 probability in the KFS data. Real estate and leasing, whose average pay

\footnotetext{
${ }^{12}$ Since no variation in business age can be measured for a single year's worth of data, the variable necessarily gets dropped from this analysis.
} 
Table 5. Job Quality by Industry for the Baseline Sample of Emerging Businesses in the Year of Founding

\begin{tabular}{|c|c|c|c|}
\hline Industry & $n$ & $\begin{array}{c}\text { Proportion with } \\
\text { health care coverage }\end{array}$ & $\begin{array}{l}\text { Proportion with } \\
\text { retirement plan } \\
\end{array}$ \\
\hline Agriculture, Forestry, Fishing, and Hunting & 26 & .27 & .08 \\
\hline Mining & 2 & .50 & .00 \\
\hline Utilities & 2 & .00 & .00 \\
\hline Construction & 228 & .28 & .09 \\
\hline Manufacturing & 521 & .28 & .08 \\
\hline Wholesale Trade & 145 & .31 & .10 \\
\hline Retail Trade & 338 & .18 & .06 \\
\hline Transportation and Warehousing & 73 & .22 & .07 \\
\hline Information & 86 & .26 & .05 \\
\hline Finance and Insurance & 137 & .25 & .10 \\
\hline Real Estate and Rental and Leasing & 122 & .10 & .05 \\
\hline Professional, Scientific, and Technical Services & 673 & .28 & .13 \\
\hline Management of Companies and Enterprises & 8 & .38 & .13 \\
\hline Administrative and Support and Waste Management & 210 & .20 & .07 \\
\hline Educational Services & 16 & .25 & .06 \\
\hline Health Care and Social Assistance & 77 & .25 & .09 \\
\hline Arts, Entertainment, and Recreation & 61 & .12 & .00 \\
\hline Accommodation and Food Services & 79 & .29 & .06 \\
\hline Other Services (except Public Administration) & 245 & .19 & .04 \\
\hline Public Administration & 2 & .50 & .50 \\
\hline Total & 3,051 & .24 & .08 \\
\hline
\end{tabular}

Source: Kauffman Firm Survey baseline year (2004), two-digit NAICS 2002, unweighted.

falls roughly in the middle of the industry distribution, offered health care benefits to its full-time employees only $10 \%$ of the time in the year of founding.

With respect to pensions, notice that in the year of founding, no industry quite reaches the overall, multiyear mean of $15 \%$ reported in Table 3 . Aside from industries with excessively small cell counts, penetration is highest at $13 \%$ in the professional, scientific, and technical services industry. On the other side of the spectrum, other service industries (except public administration) offer full-time employees retirement plans just $4 \%$ of the time. Finally, note from the bottom row of Table 5 that in the year of founding, $24 \%$ of new businesses offered health insurance and $8 \%$ offered a retirement plan. This serves as early support for Hypotheses $3 \mathrm{a}$ and $3 \mathrm{~b}$ since these numbers are less than the multiyear sample averages displayed in Table 3. Having taken stock of interindustry differences, recall that some of the multivariate estimates, in particular, the fully specified models on which we will focus, include two-digit industry dummies, and thus, control for unobserved differences between industries.

Turning now to the multivariate analyses, Tables 6 and 7 present the exponentiated logistic regression estimates, that is, odds ratios, for health insurance and pensions, respectively. In each case, the first four columns exclude the vector of two-digit industry dummies, while the second four columns include them, so that Models 5 to 8 represent "within-industry" estimates. With respect to the analysis of health insurance in Table 6 , the estimates in Model 1 imply that the probability of an establishment offering 
Table 6. Determinants of a New Business's Likelihood to Provide a Health Insurance Plan to Full-Time Employees

\begin{tabular}{|c|c|c|c|c|c|c|c|c|}
\hline Variable & Model 1 & Model 2 & Model 3 & Model 4 & Model 5 & Model 6 & Model 7 & Model 8 \\
\hline \multirow[t]{2}{*}{ Number of employees } & $1.35 * * *$ & & & $1.31 * * *$ & $1.37 * * *$ & & & $1.34 * * *$ \\
\hline & $(15.78)$ & & & (13.88) & (16.48) & & & (14.46) \\
\hline \multirow[t]{2}{*}{ Number of employees ${ }^{2}$} & $.99 * * *$ & & & $.99 * * *$ & $.99 * * *$ & & & $.99 * * *$ \\
\hline & $(-9.60)$ & & & $(-8.23)$ & $(-9.81)$ & & & $(-8.43)$ \\
\hline Profitable & & $\begin{array}{c}1.64 * * * \\
(8.28)\end{array}$ & & $\begin{array}{c}1.58 * * * \\
(6.96)\end{array}$ & & $\begin{array}{c}1.57 * * * \\
(7.47)\end{array}$ & & $\begin{array}{c}1.50^{* * * *} \\
(6.20)\end{array}$ \\
\hline Competitive advantage & & $\begin{array}{c}1.41 * * * \\
(5.03)\end{array}$ & & $\begin{array}{l}1.26^{* *} \\
(3.16)\end{array}$ & & $\begin{array}{c}1.41 * * * \\
(5.04)\end{array}$ & & $\begin{array}{l}1.28 * * \\
(3.26)\end{array}$ \\
\hline Patents & & $\begin{array}{c}1.72 * * * \\
(3.32)\end{array}$ & & $\begin{array}{l}1.64 * * \\
(2.77)\end{array}$ & & $\begin{array}{l}1.67 * * \\
(3.05)\end{array}$ & & $\begin{array}{l}1.54^{*} \\
(2.31)\end{array}$ \\
\hline Trademarks & & $\begin{array}{c}1.61^{* * * *} \\
(5.57)\end{array}$ & & $\begin{array}{l}1.36^{* *} \\
(3.14)\end{array}$ & & $\begin{array}{c}1.64 * * * \\
(5.56)\end{array}$ & & $\begin{array}{c}1.44 * * * \\
(3.60)\end{array}$ \\
\hline $\begin{array}{l}\ln \text { (Government share } \\
\text { of total sales) }\end{array}$ & & & $\begin{array}{l}1.24 * * * \\
(7.56)\end{array}$ & $\begin{array}{c}1.15^{* * * *} \\
(4.72)\end{array}$ & & & $\begin{array}{c}1.21 * * * \\
(6.79)\end{array}$ & $\begin{array}{c}1.14 * * * \\
(4.13)\end{array}$ \\
\hline Age & & & $\begin{array}{c}1.27 * * * \\
(6.14)\end{array}$ & $\begin{array}{l}1.03 \\
(0.74)\end{array}$ & & & $\begin{array}{c}1.27 * * * \\
(6.09)\end{array}$ & $\begin{array}{l}1.03 \\
(0.58)\end{array}$ \\
\hline Age $^{2}$ & & & $\begin{array}{l}.97 * * * \\
(-3.89)\end{array}$ & $\begin{array}{l}1.01 \\
(0.63)\end{array}$ & & & $\begin{array}{l}.97 * * * * \\
(-3.94)\end{array}$ & $\begin{array}{c}1.01 \\
(0.69)\end{array}$ \\
\hline Includes industry dummies & No & No & No & No & Yes & Yes & Yes & Yes \\
\hline$n$ & 17,579 & 17,630 & 16,034 & 15,893 & 17,579 & 17,630 & 16,034 & 15,893 \\
\hline Clusters & 4,396 & 4,410 & 4,343 & 4,323 & 4,396 & 4,410 & 4,343 & 4,323 \\
\hline
\end{tabular}

Notes: Shows odds ratios, statistical significance, and $t$-statistics for logistic regression models in which the dependent variable is whether a new business offered its full-time workforce a health insurance plan over the course of the previous calendar year. Estimates account for sample attrition, and standard errors account for intra-business correlation.

$* p<.05, * * p<.01, * * * p<.001$

health insurance to its full-time employees is an increasing, curvilinear function of the number of employees in the business. ${ }^{13}$ Specifically, based on the partial slope estimate for the linear measure of size, each single-unit increase in the number of workers at an establishment increases the odds that the business offers health care by a factor of about 1.35 . While this increase is somewhat offset by the negative slope coefficient associated with the quadratic size term, it nonetheless implies that adding three employees about doubles the likelihood that an employer offers a health plan. While this supports Hypothesis 1a, note that Model 1 includes no control variables and does not account for unobserved sources of variation at the industry level.

Model 2 in Table 6 speaks to Hypothesis 2a in which we argued that those new businesses with resource slack will be more likely to offer their full-time employees health insurance. Indeed, all four measures of resource slackprofitability, competitive advantage, patents, and trademarks-are associated with an increased probability that health insurance will be offered to fulltime employees, as all four measures carry statistically significant odds ratios in excess of 1 (implying statistically significant coefficient estimates in excess of 0 ). Model 3 offers a test of Hypothesis $3 \mathrm{a}$. It called for a positive

\footnotetext{
${ }^{13}$ Since the numbers displayed are exponentiated coefficients, or odds ratios, they carry values in the domain $[0, \infty]$. Therefore, an exponentiated coefficient less than 1 implies the associated raw coefficient is negative.
} 
relationship between the extent to which firms faced institutional pressures to provide health insurance to their employees, measured as the natural log of the percentage of sales attributable to public sector customers and with linear and quadratic time trends intended to capture the number of years the business has been in operation. The estimates in Model 3 support the hypothesis that increases in institutional pressures are associated with an increased probability that a new business will offer health insurance. The impact of the time trend is curvilinear, much like the relationship between size and the dependent variable in Model $1 .^{14}$

As in Model 1, neither Model 2 nor Model 3 offers a simultaneous test of the impact of all of the independent variables on the likelihood that a new business offers health insurance to its full-time employees. Model 4 addresses this issue by simultaneously including the full vector of the independent variables on the right-hand side. Not surprisingly, all of the $t$-statistics in Model 4 are smaller in magnitude than they are in the previous models. The impact of scale on the incidence of health insurance, however, remains strongly supported. The original results pertaining to resource slack emerge almost as strongly in Model 4 as they do in Model 2. The institutional measures, first included in Model 3, do not emerge quite as demonstrably as the scale and resource measures. On the one hand, the logged government share of a business's receipts remains a statistically significant, positive predictor of the incidence of health care benefits. On the other hand, neither of the time trend terms maintains its statistical significance. Still, when considered collectively, we can reject the null hypothesis that institutional pressures do not influence the dependent variable $(F=12.81, p<.0001)$.

While Models 1 to 4 offer support for Hypotheses 1a, 2a, and 3a, they still allow for the possibility that unobserved characteristics at the industry level

\footnotetext{
${ }^{14} \mathrm{By}$ relying on a binary measure of profitability, we may be allowing measurement error in profitability to bias upward the estimate for government receipts and to create the false impression of a positive, curvilinear relationship between business age and job quality. Unfortunately, the public-use version of the KFS data set does not include a continuous measure of profits or even of revenues or expenses (which would allow us to calculate a gross measure of gross margin). It does include an ordered categorical measure of profitability, however, which we eschewed in the main analysis due to its lack of interpretability, but that we use to check for robustness. When we re-run our estimates using the ordered categorical as opposed to the binary measure of profit, the estimates for government receipts do not change in any material way. Most critically, the coefficient on the government receipts variable remains significant at $p<.001$. With respect to the indication of a positive, curvilinear relationship between age and job quality, the ideal solution would be to estimate a fixed-effects (FE) model. Unfortunately, there really is no FE equivalent of a logit model as there would be for OLS, which is, in great measure, what precluded us from running one in the first place. We could, however, test this suspicion by relying on Chamberlain's (1980) conditional logit, though the conditionality requirement necessitates that all those businesses that never changed their benefits provision policies be entirely excluded from the analysis. Nonetheless, when we do this, either with the binary measure of profitability or with the more granular alternative measure, the linear and quadratic time trends measuring age retain their directionality and statistical significance. Having done all this, given the limitations of the conditional logit and the alternative measure of profitability, we cannot completely dispose of unmeasured profitability as a potential source of bias, but we gain confidence that our results are generally robust in the directionality of the relationships.
} 
Table 7. Determinants of a New Business's Likelihood to Provide a Retirement Plan to Full-Time Employees

\begin{tabular}{|c|c|c|c|c|c|c|c|c|}
\hline Variable & Model 1 & Model 2 & Model 3 & Model 4 & Model 5 & Model 6 & Model 7 & Model 8 \\
\hline Number of employees & $\begin{array}{l}1.23 * * * \\
(10.16)\end{array}$ & & & $\begin{array}{c}1.21 * * * \\
(8.65)\end{array}$ & $\begin{array}{l}1.26 * * * \\
(10.56)\end{array}$ & & & $\begin{array}{c}1.24 * * * \\
(9.10)\end{array}$ \\
\hline Number of employees ${ }^{2}$ & $\begin{array}{l}.995 * * * \\
(-5.48)\end{array}$ & & & $\begin{array}{l}.996 * * * \\
(-4.71)\end{array}$ & $\begin{array}{l}.99 * * * \\
(-5.88)\end{array}$ & & & $\begin{array}{l}.995 * * * \\
(-5.23)\end{array}$ \\
\hline Profitable & & $\begin{array}{c}2.15^{* * * *} \\
(8.86)\end{array}$ & & $\begin{array}{l}1.94 * * * \\
(7.37)\end{array}$ & & $\begin{array}{c}2.00 * * * \\
(8.06)\end{array}$ & & $\begin{array}{c}1.80^{* * * *} \\
(6.51)\end{array}$ \\
\hline Competitive advantage & & $\begin{array}{l}1.29 * * \\
(2.83)\end{array}$ & & $\begin{array}{l}1.25^{*} \\
(2.25)\end{array}$ & & $\begin{array}{l}1.32 * * \\
(3.01)\end{array}$ & & $\begin{array}{l}1.26^{*} \\
(2.37)\end{array}$ \\
\hline Patents & & $\begin{array}{c}2.07 * * * * \\
(3.51)\end{array}$ & & $\begin{array}{l}1.85^{* *} \\
(2.88)\end{array}$ & & $\begin{array}{c}2.09 * * * \\
(3.61)\end{array}$ & & $\begin{array}{l}1.76 * * \\
(2.59)\end{array}$ \\
\hline Trademarks & & $\begin{array}{c}1.48^{* * * *} \\
(3.49)\end{array}$ & & $\begin{array}{l}1.27 * \\
(1.98)\end{array}$ & & $\begin{array}{c}1.54 * * * \\
(3.83)\end{array}$ & & $\begin{array}{l}1.36^{*} \\
(2.49)\end{array}$ \\
\hline $\begin{array}{l}\ln \text { (Government share } \\
\text { of total sales) }\end{array}$ & & & $\begin{array}{c}1.31 * * * \\
(8.17)\end{array}$ & $\begin{array}{c}1.23 * * * \\
(5.90)\end{array}$ & & & $\begin{array}{c}1.27 * * * \\
(7.27)\end{array}$ & $\begin{array}{c}1.20^{* * * *} \\
(5.11)\end{array}$ \\
\hline Age & & & $\begin{array}{c}1.54 * * * \\
(7.82)\end{array}$ & $\begin{array}{c}1.29 * * * \\
(4.22)\end{array}$ & & & $\begin{array}{c}1.55^{* * * *} \\
(7.77)\end{array}$ & $\begin{array}{c}1.30 * * * \\
(4.23)\end{array}$ \\
\hline Age $^{2}$ & & & $\begin{array}{l}.95^{* * *} \\
(-5.44)\end{array}$ & $\begin{array}{c}.97 * \\
(-2.32)\end{array}$ & & & $\begin{array}{l}.94 * * * \\
(-5.49)\end{array}$ & $\begin{array}{c}.97 * \\
(-2.44)\end{array}$ \\
\hline Includes industry dummies & No & No & & -8 & 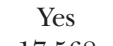 & 10 & 1.s & Yes \\
\hline$n$ & 17,580 & 17,630 & 16,035 & 15,893 & 17,568 & 17,618 & 16,024 & 15,882 \\
\hline Clusters & 4,396 & 4,410 & 4,343 & 4,323 & 4,394 & 4,408 & 4,341 & 4,321 \\
\hline
\end{tabular}

Notes: Shows odds ratios, statistical significance, and $t$-statistics for logistic regression models in which the dependent variable is whether a new business offered its full-time workforce a retirement plan over the course of the previous calendar year. Estimates account for sample attrition, and standard errors account for intra-business correlation.

$* p<.05, * * p<.01, * * * p<.001$

could be driving the results. For example, it could be that certain industries are more likely than others to offer jobs with benefits, and those businesses in these industries are disproportionately large, disproportionally wellresourced, or subject to a disproportionately high degree of institutional pressure. Models 5 to 8 are intended to preclude the confounding impact of industry heterogeneity by including on the right-hand side a full vector of two-digit industry codes. Aside from that, Models 5 to 8 are analogous to Models 1 to 4 . In the aggregate, the estimates that include industry controls are qualitatively identical to those that do not. This implies that industry differences are not driving the initial set of results. Furthermore, in the presence of the industry controls, the estimates can be construed as "withinindustry" estimates. Meaning, even relative to other businesses in the same industry, those new employers that are larger, better-resourced, and under greater institutional pressure are more likely than others to offer full-time employees some sort of health insurance plan. Nonetheless, as was the case in the absence of industry controls, the effects of age fail to maintain statistical significance in the presence of the other variables.

The eight models in Table 7 are analogous to those in Table 6, the only difference being that they test the hypotheses related to retirement benefits 
or pensions. Indeed, the results support Hypotheses $1 \mathrm{~b}, 2 \mathrm{~b}$, and $3 \mathrm{~b}$. Moreover, the predictors retain their statistical significance even when included in a single estimate simultaneously and when introduced in the presence of two-digit industry dummies. In contrast to the results in Table 6, however, the two indicators of business age intended as a measure of institutional pressure continue to maintain their statistical significance even in the presence of the other predictor variables as well as the industry controls. Therefore, the results offer strong support for the three pension-related hypotheses.

\section{Discussion}

These results are best understood graphically. All of the figures are founded upon the fully specified models inclusive of industry dummies, Model 8 in Table 6 and Model 8 in Table 7. Figure 1 presents fitted probabilities that a new employer offers its full-time employees health insurance (solid line) and a pension (dashed line) as a function of establishment size. All other variables are held at their sample means. While the likelihood of offering a retirement plan is always lower than that associated with health care, both probabilities are highly sensitive to the number of employees in the workplace. Given the curvilinear nature of the relationship, this sensitivity is even greater for the smallest businesses. With just one employee, the probability that a new employer offers health insurance is just .15. The same business, carrying all of the same mean values for the independent variables, will offer its full-time employees health insurance with a probability of .76 once it reaches 25 employees. ${ }^{15}$ Similarly, the "mean" business in the sample, constrained to just one employee, will offer a retirement plan only $7 \%$ of the time, which rises to $39 \%$ at the 25 -employee mark. Suffice it to say, the values plotted in Figure 1 are consistent with Hypotheses 1a and 1b. Our data do not permit us to disentangle the many potential sources of scale effects, for example, efficiency wages (Rebitzer 1993; Fairris and Alston 1994), production interdependence (Rebitzer and Taylor 1995), ILMs (Hollister 2004), or something else. Nonetheless, our findings show that policies to boost job quality in new firms must address the actual or perceived high fixed costs associated with the provision of health insurance and pensions (Sels et al. 2006a, 2006b).

While the impact of relaxing resource constraints certainly pales in comparison to the impact of scale, the regression results clearly show that resource slack, too, drives job quality, even after accounting for scale. This finding is noteworthy, since the "all-encompassing" nature of scale has been shown to dampen the negative effects of resource constraints in wage studies (Knoke 1994). One reason may be because in a sample of new businesses, scale is less likely to be a proxy for, and therefore, less likely to be correlated with, resource measures, as evidenced by Table 3. Figure

\footnotetext{
${ }^{15}$ While 25 is within the domain of the scale variable, relatively few businesses in the KFS ever reach this size. In the final year for which we have data, just 78 businesses reported 25 or more employees.
} 
Figure 1. Fitted Probability That an Emerging Business Offers Its Full-Time Employees Health Insurance and a Retirement Plan as a Function of Its Size

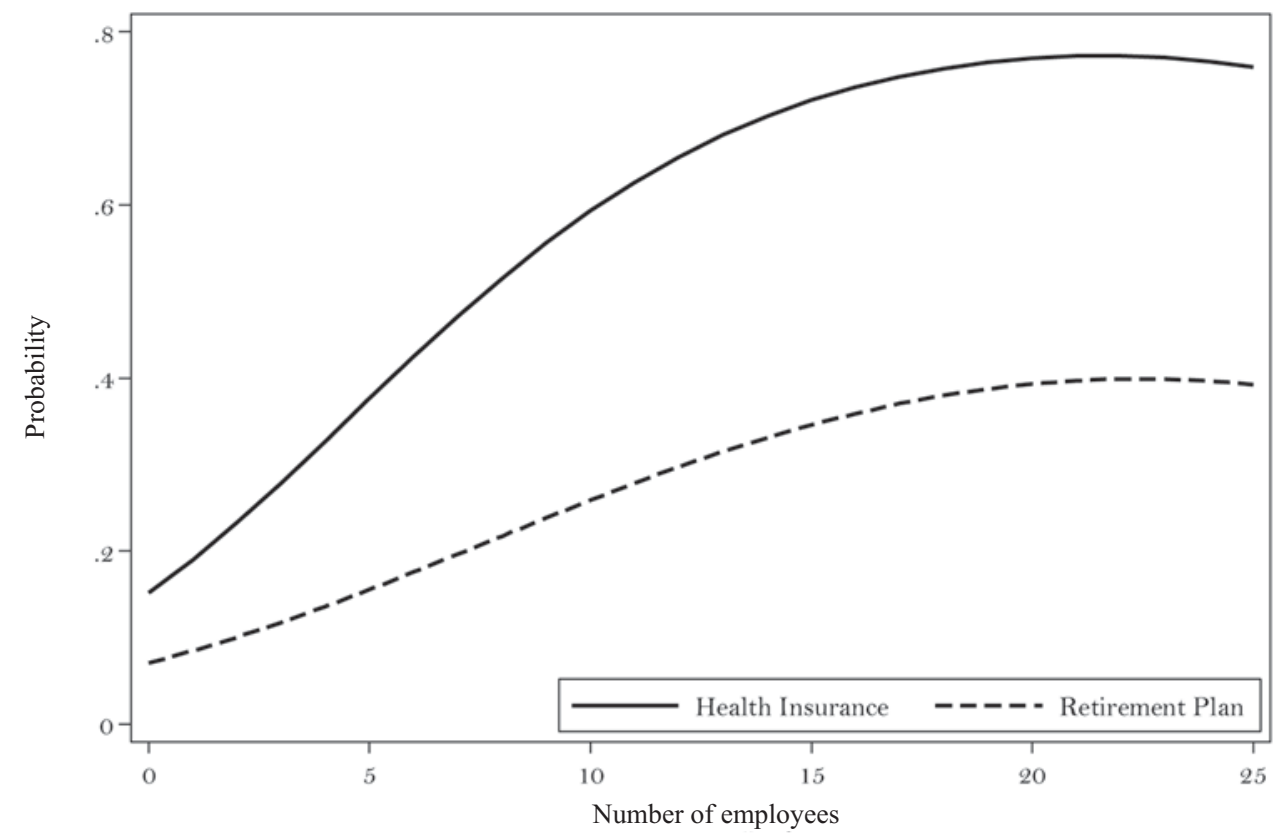

Note: Fitted probabilities for health insurance and retirement plan derived from Model 8 in Table 6 and Model 8 in Table 7, respectively, with all non-focal independent variables held at their sample means.

2 displays the marginal probability that each benefit will be offered as a function of each of the four binary variables used to measure resource slack. We already know that both health insurance and pensions are sensitive to whether a new business is profitable, is perceived to hold a competitive advantage, and is holding intellectual property in the form of patents or trademarks. The figure, again based on the estimates in Model 8 in Tables 6 and 7 , offers a sense of the magnitude of these effects. Recall that all of these differences are statistically significant. Using profitability as an example, consider the probability that the mean business in the sample will offer health insurance to its full-time employees. If the company is not profitable, it will offer health insurance with probability .26. If it reports a positive profit, that likelihood increases to .32. However, from Table 2, we know that fewer than half of the business-years in the sample benefit from this increment associated with profitability. The situation is even truer of patents. Those businesses holding at least one patent provide health insurance with .37 probability, whereas the $97 \%$ of the sample that do not report holding any patents instead offer health insurance with just .29 probability. Analogous results obtain with respect to pensions. This finding suggests that while not of the same order of magnitude as scale, "resource poverty" (Welsh and White 1981) is a driver of job quality, as theorized in Hypotheses 2a and 2b. Those firms that have profits or the capacity to generate rents-be they 
Figure 2. Fitted Probability That an Emerging Business Offers Its Full-Time Employees Health Insurance and a Retirement Plan, with and without Four Measures of Resource Slack

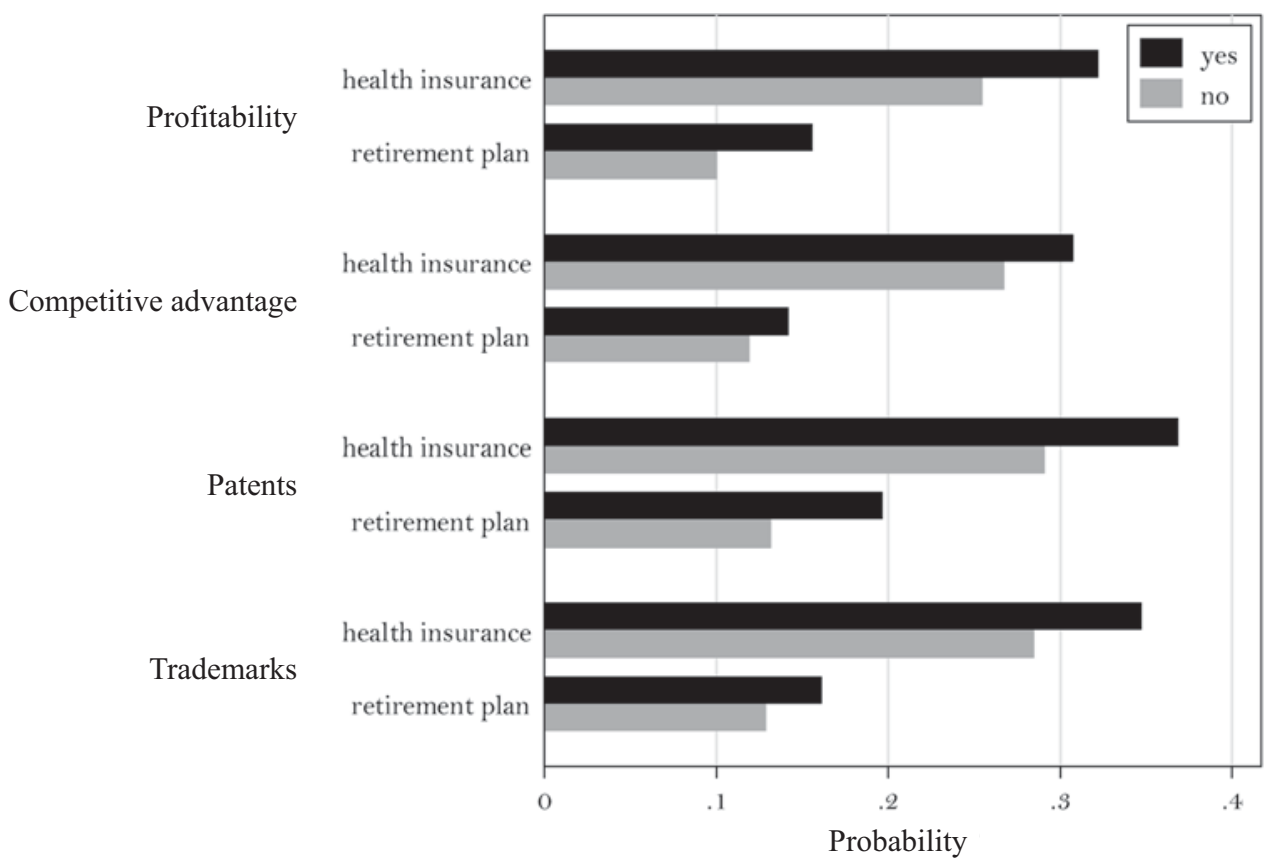

Note: Fitted probabilities for health insurance and retirement plan derived from Model 8 in Table 6 and Model 8 in Table 7, respectively, with all non-focal independent variables held at their sample means.

through competitive advantage (Porter 1980) or intellectual property-are more likely than others to offer high-quality jobs.

The finding that resource constraints attenuate the quality of jobs created by new ventures sheds light on the interplay of employers and employment policy with respect to job quality. Intense product market competition and the "liability of newness" (Stinchcombe 1965) present entrepreneurs with a conundrum. They can be "high-road" employers and increase their costs by providing fringe benefits, thereby risking failure; or, they can offer jobs of lower quality, just like their competitors. Indeed, Paul Osterman and Beth Shulman (2011) offer numerous examples of the precarious position in which "high-road" employers have been placed, in some cases forcing them to abandon the "high road," and in other cases forcing them out of business altogether. More fundamentally, irrespective of which direction entrepreneurs choose, the mere fact that these costs must figure into the marginal calculus associated with making the initial founding decision may reduce the incidence of new venture formation relative to a situation in which these costs were borne by the public. Therefore, much like public investments in physical infrastructure that pave the way for healthy competition, similar investments to promote entrepreneurship and the innovation that arises from it-in the form of subsidized health insurance or state-run 
Figure 3. Fitted Probability That an Emerging Business Offers Its Full-Time Employees Health Insurance and a Retirement Plan as a Function of the Public Sector Share of Its Receipts

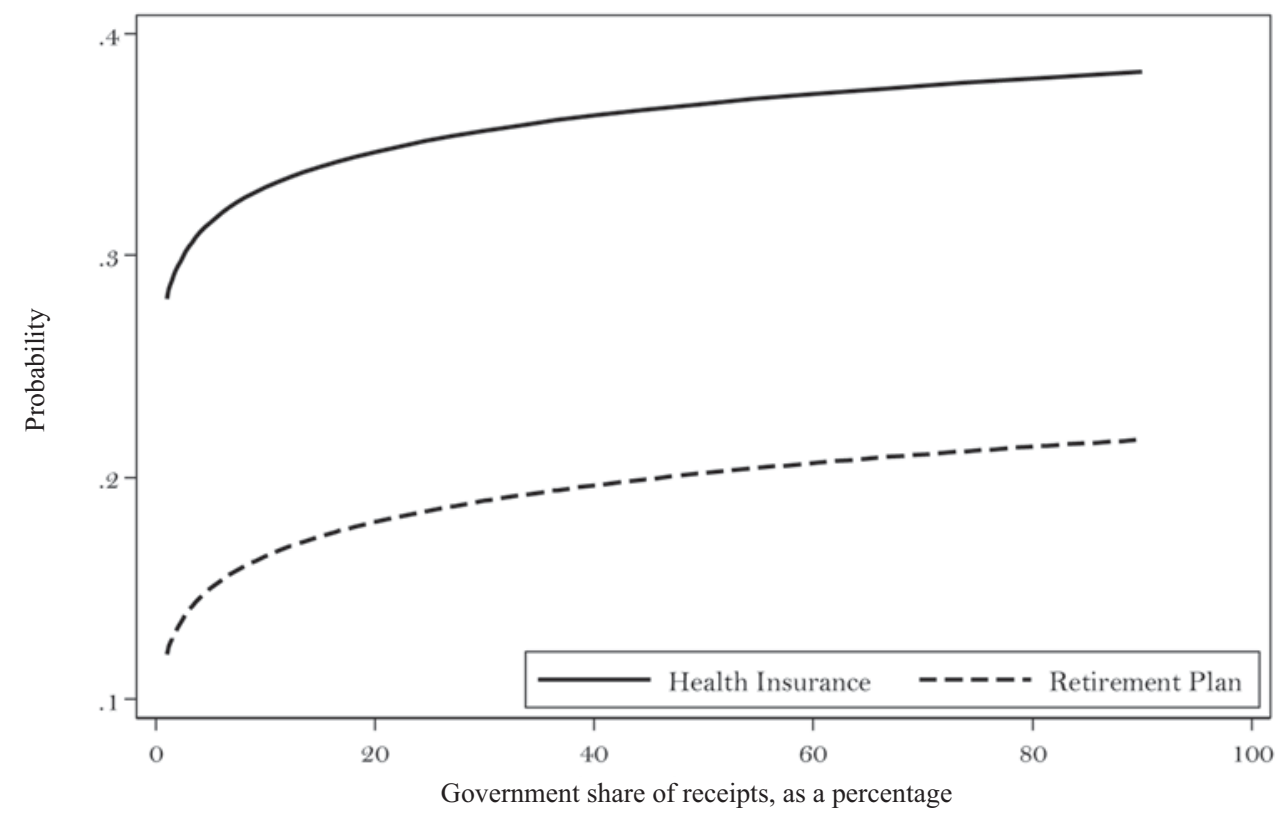

Note: Fitted probabilities for health insurance and retirement plan derived from Model 8 in Table 6 and Model 8 in Table 7, respectively, with all non-focal independent variables held at their sample means.

pension programs, for example-could well be justified on economic efficiency grounds (Lerner 2009).

Institutional pressures were predicted to be positive drivers of job quality. With respect to health insurance, Hypothesis 3a, the evidence is mixed. On the one hand, the probability that a budding employer offers health insurance is an increasing function of its share of sales attributable to public sector customers. This implies that those emerging businesses that are more visible to regulatory authorities, and thus, more highly exposed to normative pressures, are more likely to provide high-quality jobs (Oliver 1991; Osterman and Shulman 2011). Figure 3, again generated by fitting values from estimates in Model 8 in Tables 6 and 7, illustrates this. The solid line depicts estimated probabilities for health insurance, where all variables except the government share of receipts are held at their sample means. On the other hand, the estimates in Table 6 show that little if any discernible relationship is observed between the age of a business in the KFS and the likelihood that it offers health insurance, at least in our sample of new and young businesses. Hypothesis 3b emerges with more statistical support. In this case, Figure 3 again makes clear that increases in the public sector share of a business's customer base are associated with increases in the likelihood that the employer offers a retirement plan. Furthermore, based on the estimates in Table 7, the age of a business-from zero to five years old-positively predicts the likelihood that it will offer some form of a pension plan. 
In some sense, this squares with the notion that new firms will feel increasing pressure to demonstrate legitimacy as they mature from start-ups into young firms. While the estimates associated with the time trend are in the hypothesized direction in this case, the practical import of age appears fairly small. That is, despite the statistical significance of the slope coefficients for age, age is of little economic significance. Holding every covariate steady at its mean, a new business in the KFS offers a retirement plan with .10 probability, a number that rises to .16 by its fifth year of operation. This is truer with respect to health insurance. Here, the probability increases from .28 to .33 , on average, less than one percentage point per year. Put another way, as was the case with our discussion on resource poverty, the magnitude of the effect of institutional pressures on job quality is easily dwarfed by scale. Even at $0 \%$ government receipts and even in the year of founding, $55 \%$ of "large" employers in the KFS-those with 10 employees-offer health care. In contrast, consider a five-year-old business for which $95 \%$ of sales are to government customers-both "extreme" values given the way institutional pressure is measured. If it has just three employees, the likelihood it will offer health insurance to its full-time employees is just $37 \%$.

The finding that those new businesses serving federal, state, and local governments are more likely than others to provide health and retirement benefits suggests an important avenue for policy. Since health and pension benefits are structured on a constellation of public and private sector institutions, and the employment relationship is assumed to be the primary provider of both health insurance and tax-qualified retirement savings, businesses that do not offer these benefits are not establishing sustainable employment relationships. Rather, the jobs they create impose an economic externality on society-at-large (Osterman and Shulman 2011). Procurement policies, however, can be used strategically to boost job quality. Our findings call for the establishment and enforcement of federal and even local standards for job quality, akin to the "prevailing wage" mandate promulgated on the federal level by the Davis-Bacon Act for construction workers and the McNamara-O'Hara Service Contracts Act for service workers, or equivalent to the "living wage" requirements that local governments often place on their contractors and on any businesses receiving taxpayer-funded financial assistance (Adams and Neumark 2005; Holzer et al. 2011). Based on the evidence, when combined with an earnest attempt to share the fruits of government contracting with entrepreneurs, such policies would increase the probability that new ventures offer health and pension benefits without compromising their financial viability. Aside from the direct impact, such approaches could ultimately reshape employment norms by establishing or re-establishing higher standards for private sector job quality, beyond those specific businesses that trade with the government. These shifts are most likely to happen in industries dense with government business such as health and education, both of which happen to be replete with low-quality jobs (Osterman and Shulman 2011).

While Hypotheses 3a and 3b are only partially supported, perhaps an additional lesson can be gleaned from the relatively weak evidence linking 
business age to job quality. Specifically, a strong path dependency with respect to job quality is observed. Indeed, relative to the quality of jobs created just as a business is established, relatively little improvement in job quality takes place over the first five years of the business's life. That is, while businesses show some improvement, the true determination of job quality occurs at the time of founding, consistent with the theory of "imprinting" put forth by Baron, Burton, and Hannan (1996).

\section{Comparisons with Economy-wide Data}

Figure 1 began to illustrate the importance that scale plays as a driver of job quality in emerging businesses. Its full impact requires a comparison of the results found here to broader, economy-wide data on benefits offer rates. We present comparative data from one such national source. The National Compensation Survey (NCS), produced by the Bureau of Labor Statistics (BLS) in the U.S. Department of Labor (DoL), provides comprehensive measures of benefit incidence, namely the share of establishments offering any form of health care insurance. The benefit is defined very broadly as it is in the KFS. The full sample includes about 17,500 establishments per year, of all sizes, and the survey results are weighted to account for sample probability and nonresponse. The response rate in the most recent year was about $70 \% .{ }^{16}$ BLS field economists have collected the data from establishments on an annual basis since 1996. Therefore, we can use the NCS data to construct benchmark time series for 2004 to 2009, the entire span for which we have KFS data. ${ }^{17}$

Figure 4, which focuses on health insurance coverage, plots a total of four data series- two based on the estimates presented above and two data series culled from the NCS. The solid line, based on NCS data, represents the economy-wide probability that an establishment of any size will offer a health care plan, by year, for the period 2004 to 2009 . Note that the series hovers around .60 , exceeding it in the years prior to the economic slowdown. The data series represented by the solid line is useful from a policy perspective and is thus presented here. Because the measure is not size-adjusted, however, it does not allow for a fair comparison to a data set of new, and therefore, generally much smaller businesses. A more suitable comparison is represented by the dashed line. It represents the share of establishments with one to five employees that offer any form of health care coverage. This is the smallest size category of establishments that that can be identified in the NCS. Note that over the 2004 to 2009 period, this series fluctuates in the range $[.40, .46]$. That is, it always exceeds fitted values from Model 8 in

\footnotetext{
${ }^{16}$ For more information on the National Compensation Survey, see http://www.bls.gov/ncs/home .htm (accessed October 1, 2011).

${ }^{17}$ With respect to the NCS data, the "all establishments" series is published; however, the "1-5 employees" series is unpublished and was made available by special request. The Kaiser Family Foundation has also developed a rich panel data set useful for analyses like these. It employs the firm rather than the establishment as its unit-of-observation, however, making it less comparable to the KFS data. For more information, see Kaiser Family Foundation (2011).
} 
Figure 4. Probability That an Emerging Business Offers Its

Full-Time Employees Health Insurance, over Time

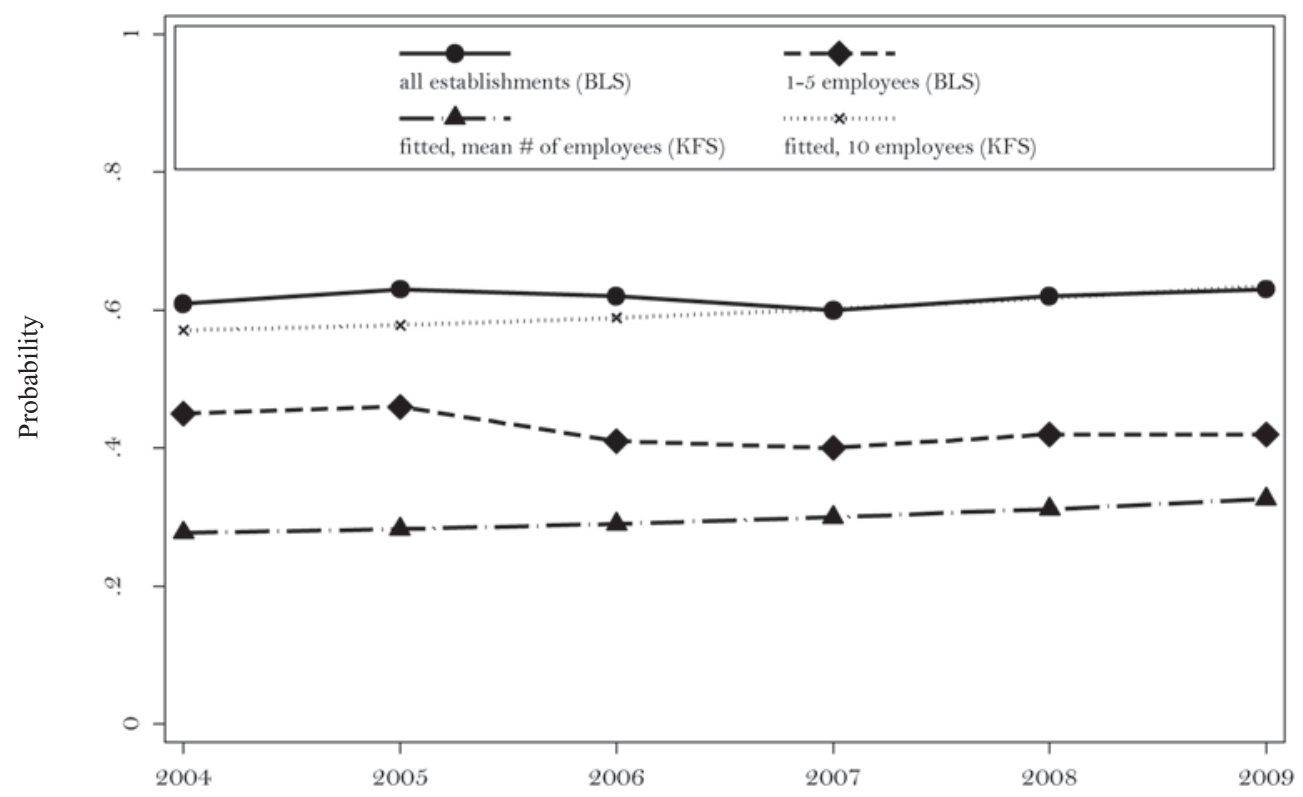

Note: National Compensation Survey (NCS) data provided by the Bureau of Labor Statistics. NCS data on establishments with 1-5 employees are unpublished. The fitted values for the Kauffman Firm Survey (KFS) data derived from Model 8 in Table 6, with all non-focal independent variables held at their sample means.

Table 6 when all of the variables are held at their sample means. These are represented by the dot-dash line which peaks at .33 in 2009. However, when these fitted values are size-adjusted such that all of the variables except size are held at their sample means-as they are in the dotted series, the series converges with the "all-workplaces" NCS data. In this case, with workplace size held at 10 employees, Model 8, estimated above, predicts that new businesses in the KFS, by their fourth year of operation, offer their full-time employees health insurance with the same probability as the average establishment of any size across the economy.

The dominance of employer scale as a driver of job quality in new businesses can also be seen by examining fitted values for retirement benefits in the context of broader, national data. Once again, the NCS canvasses for information on retirement plans, providing rich comparative data just as it did in the health insurance domain. ${ }^{18}$ Figure 5 plots these economy-wide data series for pension plan incidence along with fitted values from Model 8

\footnotetext{
${ }^{18}$ The National Federation of Independent Businesses (NFIB), an organization that lobbies on behalf of small businesses, regularly surveys small-scale employers on a variety of topics related to small business performance and behavior. In 2005, it asked a sample of about 750 such employers, 698 of whom responded, whether their business sponsors a pension program for at least some of its employees. Of those firms with one to nine employees, 25.6\% responded affirmatively. For more information, see NFIB (2005).
} 
Figure 5. Probability That an Emerging Business Offers Its Full-Time Employees a Retirement Plan, over Time

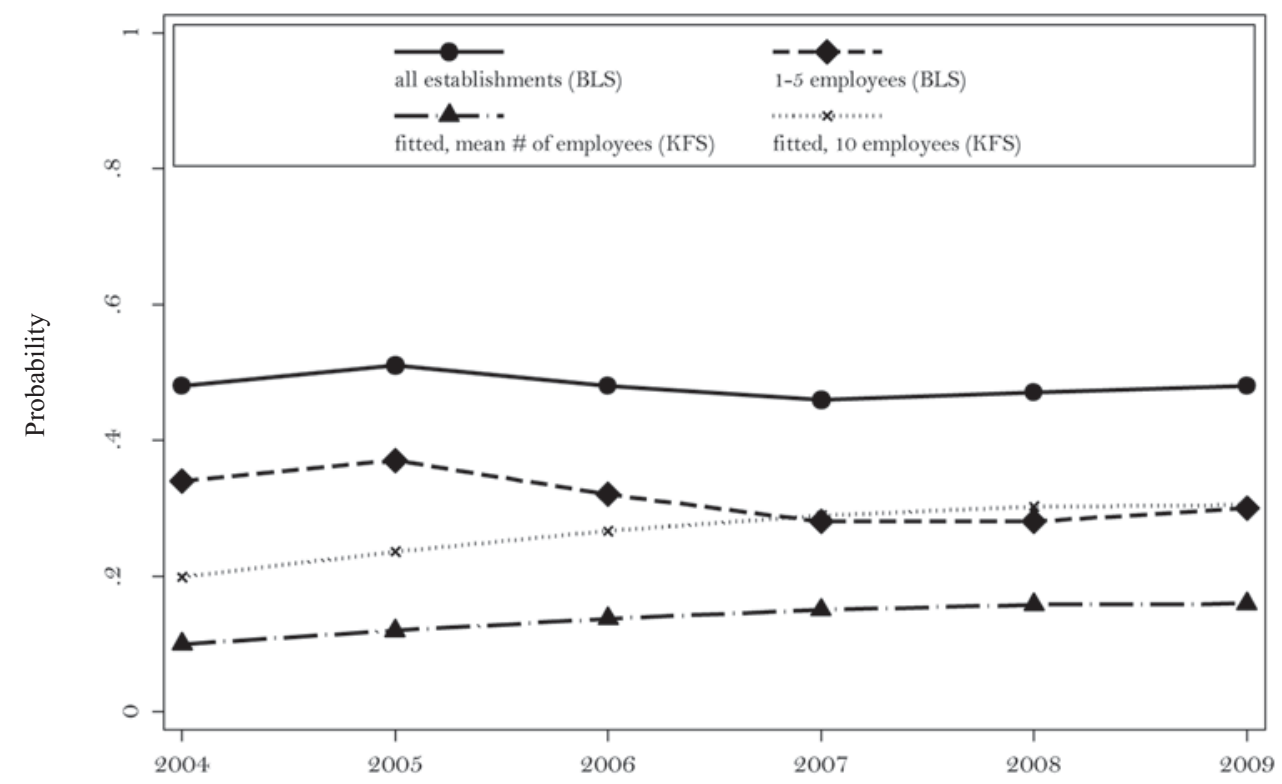

Note: National Compensation Survey (NCS) data provided by the Bureau of Labor Statistics. NCS data on establishments with 1-5 employees are unpublished. The fitted values for the Kauffman Firm Survey (KFS) data derived from Model 8 in Table 7, with all non-focal independent variables held at their sample means.

in Table 7. Analogously to Figure 4, the solid line represents the share of establishments of all sizes nationwide offering their employees any sort of retirement plan. It peaks at .51 in 2005 but never falls below .46 over the sixyear observation period. Once these data are size-adjusted, incidence rates from the NCS fall to as low as .28 in 2007 and 2008, again represented by the dashed line. When one compares those probabilities to fitted probabilities from the KFS data, with all independent variables including size held at their sample means-shown as the dot-dash line-one sees that new employers are much less likely than existing ones to provide their full-time employees with any sort of retirement benefit. Furthermore, even after recasting the fitted values for the KFS data by setting the number of employees to 10-illustrated with the dotted line-new employers barely exceed the observed economy-wide probabilities for establishments with just one to five employees.

The data suggest a strong distinction to be made between the comparative analysis of health insurance incidence in Figure 4 and that of retirement benefits depicted in Figure 5. With respect to health care, fitted values for new employers with 10 workers actually converge with national data on established employers of all sizes. With respect to retirement benefits, even KFS businesses with 10 workers-about four times the size of the mean firm in the sample-are essentially no more likely than established employers 
with just one to five workers-to offer pensions. Nonetheless, in both cases, the evidence is clear that scale drives job quality when job quality is defined by the incidence of these two benefits.

Our results are consistent with earlier economy-wide analyses of these benefits (Kalleberg and Van Buren 1996; Belman and Groshen 1998; Hollister 2004). In contrast to received research on job satisfaction (Curran and Stanworth 1981), for example, these size effects persist even in the presence of industry controls. What is more, the evidence suggests that when new businesses create low-quality jobs, they do so because they start out small and do not grow. In a way, this finding is consistent with recent evidence suggesting that most small businesses start and remain very small (Haltiwanger et al. 2011), sometimes, as a matter of choice (Hurst and Pugsley 2011). Collectively, Figures 1, 4, and 5 suggest that policies aimed at improving the quality of jobs created by entrepreneurs cannot ignore the impact of scale.

\section{Limitations and Future Research}

This study has a number of limitations, some of which evoke potential "next steps." First, its use of binary dependent variables no doubt obscures a great deal of variation in the nature and generosity of the health care and pension plans offered by businesses in the sample. While the KFS data do not allow for a more finely grained measure, the likelihood that the health insurance coverage or retirement plans offered are more generous than those offered by established firms is slight (Brown and Medoff 2003). With respect to health insurance, for example, recent data show that workers in firms with fewer than 200 employees, on average, absorb higher deductibles for health coverage than do workers in larger firms (Kaiser Family Foundation 2011). New employers are also far less likely than established employers to offer relatively generous defined-benefit pension plans (Beam and McFadden 2001), in part because none of the new forms of retirement plans authorized by Congress specifically for small businesses are of this type (Purcell and Graney 2002). As a result, this study's use of binary measures for benefits incidence assuredly leads to an understatement rather than an overstatement of the deficit in job quality attendant to new businesses.

Second, the study does not account for wages, which one could reasonably assert are the most fundamental element of job quality. ${ }^{19}$ While this issue should be particularly problematic for an economic conceptualization of job quality like the one employed here, and despite fundamental economic theory to the contrary (Smith 1776 [1982]), studies focused on the impact of firm size or firm age on total remuneration suggest that wages and benefits move in tandem (e.g., Mellow 1982; Brown, Hamilton, and Medoff 1990; Kalleberg and Van Buren 1996; Hamermesh 1999; Hollister 2004).

\footnotetext{
${ }^{19}$ For a detailed, empirical examination of job quality as assessed by wages, see Holzer et al. (2011).
} 
Larry Hunter (2000) reached a similar conclusion in his study of job quality in nursing homes, where an entire bundle of job quality measures cohered tightly. Brown and Medoff (2003) reasoned that the positive association results from the fact that firms that pay more are also more apt to seek out tax-advantaged forms of compensation, such as health care coverage or deferred compensation. Also possible is that the theory of compensating wage differentials would hold if empirical studies could adequately account for unobservable characteristics of workers and workplaces.

In the case of the workplaces studied here, these unobservable workplace characteristics would likely come in the form of psychological rewards. As noted above, we deliberately excluded these elements of job quality from our analysis; however, one can imagine that those voluntarily opting out of employment at large, established firms into jobs in start-up companies derive utility from increased autonomy (Herzberg 1968 [2003]; Hundley 2001; Shane 2003; Hurst and Pugsley 2011). While these newly created jobs fare poorly on the economic dimension, many of them would likely score quite well on a more psychologically oriented measure of job quality, one that captures constructs such as job enrichment, job satisfaction, and control over one's own work (Heneman, Tansky, and Camp 2000; Tsai, Sengupta, and Edwards 2007). In the case of the KFS data, because high-technology ventures are oversampled, this notion is a distinct possibility.

One way to sort out this issue of unobserved, noneconomic facets of job quality would be to conduct qualitative interviews of employees and owners at the KFS firms to get a sense of whether these newly created jobs would score highly on these alternative measures. Indeed, the most comprehensive measure of job quality would probably include a mix of economic, psychological, and even sociological constructs, akin to the measure developed by Jencks, Perman, and Rainwater (1988). Therefore, one logical next step for this research program would be to conduct a large-scale, multilevel analysis of individual employees nested in a wide range of employment settings, using an instrument that includes the breadth of survey items required to construct this multifaceted measure of job quality. In addition to broadening our conceptualization of job quality and facilitating an examination of the ways that its psychological and economic elements co-vary, this exercise would help us address unobserved differences among workers-the supply side. To the extent that job quality is in the eye of the beholder, as Kalleberg (2011) argued, it could be the case that many of those workers holding the very jobs created by entrepreneurs in this study did not actually want or need health care or retirement benefits. For example, a person may be more comfortable "striking it out on their own" if they can access health insurance through their spouse or partner (Aldrich and Cliff 2003). To the extent this scenario is true, it makes sense for entrepreneurs to provide other benefits such as wages or autonomy in place of health insurance. Of course, as we noted earlier, even where this is true, one could reasonably question whether policy should place entrepreneurs in the position of having to think strategically about whether to offer health insurance. 
The richness and the longitudinal nature of the KFS data also come with tradeoffs. That all of the firms are of the same cohort-started in 2004 and observed annually-no doubt purges the data of some sources of variation that could otherwise contaminate statistical estimates. For example, a oneyear-old firm might not feel the same degree of normative pressure to offer health insurance if it celebrates its first birthday in 2005 as opposed to 1975 . The single-cohort design, however, also yields a data set without any independent variation between firm age and calendar time. That is, all firms were one year old in 2005, two years old in 2006, and so on. Had macroeconomic conditions been reasonably stable over the observation period, then we could more credibly assume that the time trend was a reliable proxy for the age of the firm. As it turns out, we know that economic conditions worsened over the 2004 to 2009 period. Therefore, these forces cannot be ruled out as one source driving the curvilinearity of job quality as a function of time, nor can they be ruled out as a source of measurement error with respect to business age, yielding the weaker-than-expected results for $\mathrm{Hy}$ potheses $3 \mathrm{a}$ and $3 \mathrm{~b}$. Aside from the single cohort design, the sample is, of course, intentionally limited to 2004 start-ups, most of which are small relative to average-size workplaces in the United States. Therefore, while inferring that larger, established firms are more likely to offer high-quality jobs is reasonable, this analysis does not allow us to make a ceteris paribus comparison unless we are willing to generalize well outside the age and size bounds of the sample. In short, we cannot hold firm characteristics and industries constant, and then examine the effect of age or size-across their entire continua-on the probability of a firm offering a particular benefit. Perhaps the best opportunity for doing this would be the National Establishment Time Series (NETS) data recently employed by David Neumark et al. (2011) to address the job quantity question.

In addition to follow-up studies that broaden the job quality construct and the size and age range of firms sampled, we can begin to address other questions using the data we already have. For example, it would be interesting to examine job quality as a driver of economic outcomes for new businesses. In particular, how does the quality of jobs created by new employers influence their likelihood of survival and their performance relative to other firms? Given the nontrivial failure rates of new firms (Carroll and Hannan 2000; Smith 2011), the examination could be motivated from a policy perspective. It could also be motivated by studies linking business strategy, employment models, and outcomes for companies and their employees (e.g., Arthur 1992, 1994; Hunter, Bernhardt, Hughes, and Skuratowicz 2001; Hunter and Lafkas 2003; Batt and Nohara 2009), which, thus far, have concentrated mainly on the analysis of established firms. While these studies consider the intersection of product market and labor market forces, an additional stream of research could build on the emerging literature that considers how variation in a firm's capital structure affects its behavior in the labor market (e.g., Clark 2009; Lazonick 2009; Bacon, Wright, Scholes, and Meuleman 2010). More specifically, does a new venture's financing 
choices impinge on the quality of the employment opportunities created by these new employers?

Given the importance of newly emerging firms as employers, this research begins to address the bias that employment relations scholars have long held for large, established employers such as General Motors or Walmart, likely owing to the field's roots in collective bargaining (Kaufman 1993). Even for those who will continue to focus on more-established, larger employers, the study offers a rare look into the origin as opposed to the existence of jobs. This matters, because as we note above, an established employer generally begins as a start-up whose origins leave a lasting imprint on its employment model (Baron et al. 1996), namely, the ways it ultimately chooses to manage workers once it matures (Cardon and Stevens 2004).

\section{Conclusion}

The reality is that most new businesses are more likely to have two to three employees, not 10 or 25. Furthermore, as reported in Table 3, most entrepreneurs do not have slack resources, except for perceptions of competitive advantage, and most are not susceptible to institutional pressures. Consequently, in the net, after accounting for numerous sources of variation, it becomes apparent that new businesses are unlikely to offer high-quality jobs, and the probability of their doing so increases only marginally over the employer's first five to six years of operation. Relative to all other employers across the economy, new employers, challenged mainly by their small scale, are generally unlikely to offer health insurance or a pension plan to their full-time employees. As a result, Haltiwanger et al. $(2009,2011)$ were correct to shift the focus of policy recommendations from small firms to new and growing firms. We concur and add that policy solutions intended to encourage business start-ups need to be tempered with policies that encourage not only the long-term growth of these firms but also sustainable employment relationships that do not displace health and retirement costs onto societyat-large. Consequently, while received research has made clear that entrepreneurship drives job creation, particularly when one construes job creation from a purely quantitative perspective, this study grafts a qualitative dimension onto the job creation discussion and shows that by and large, new businesses generally do not create jobs that provide any form of a health insurance plan or a retirement plan. Those that do generally do so early in the business's existence, as the year-to-year growth in probability is small relative to the marginal impact of movements in other predictors of job quality.

Nonetheless, one can argue it would be naïve to assert that entrepreneurs are simply choosing to be "low-road" employers. First, we theorize three organizational and production-related attributes expected to influence the probability that a firm provides its full-time workforce with health and pension benefits-scale, resource slack, and institutional pressures. We then 
show that in a sample of new businesses, these variables, indeed, drive job quality as hypothesized. But, our findings must be considered in light of the fact that the mean organization in the data set, and by extension, most new businesses, are likely to score very low on these attributes. That is, they are likely to lack the resources required (or perceived by entrepreneurs to be required) to fund health benefits or a pension plan. Furthermore, they are unlikely to be subjected to the sorts of institutional pressures that would encourage them to offer generous benefits. But most critically, they are likely to establish themselves as small in scale and to remain small into the foreseeable future. The analysis above underlines the penalty to job quality associated with smallness. The effect of scale on the incidence of health care coverage and retirement benefits is undeniable, even in a data set limited to new, and therefore, generally very small businesses.

Keep in mind that not only have entrepreneurs been susceptible to the same market and institutional forces as other economic actors (Osterman and Shulman 2011) but also only recently and not by their own choice have they been labeled "job creators" and assigned a specific task with respect to economic recovery. What our study reveals is that in the current economic climate and under the current policy regime, entrepreneurs are not effectively encouraged to create sustainable employment relationships in the form of high-quality jobs, where quality is defined in admittedly narrow, economic terms.

While this study is only meant to establish a baseline understanding of the quality of jobs created through entrepreneurship, our findings should have immediate policy implications. Indeed, "small" businesses-those with fewer than 500 employees - constitute more than $99 \%$ of employing firms in the United States, providing jobs for more than half of all private sector employees. ${ }^{20}$ Similarly, in 2007, the last year before the present economic slowdown, (non-start-up) "young" firms-defined as being one to five years old-accounted for nearly 8 million of the 12 million new jobs added (Stangler and Litan 2009). Although some see this as evidence that entrepreneurial job creation is the key to eventual economic recovery, our analysis calls for a more cautious and more nuanced policy response than one that simply encourages job creation per se. While such policies would be a direct response to a troubling and very transparent headline unemployment rate, they would do little to address the more structural crisis in job quality that pre-dates and will likely outlast the present recession.

\section{References}

Adams, Scott, and David Neumark. 2005. The effects of living wage laws: Evidence from failed and derailed living wage campaigns. Journal of Urban Economics 58(2): 177-202.

Aldrich, Howard E., and Jennifer E. Cliff. 2003. The pervasive effects of family on

${ }^{20}$ See http://www.sba.gov/advocacy/7495/8420 (accessed July 5, 2011). 
entrepreneurship: Toward a family embeddedness perspective. Journal of Business Venturing 18(5): 573-96.

Aldrich, Howard E., and C. Marlene Fiol. 1994. Fools rush in? The institutional context of industry creation. Academy of Management Review 19(4): 645-70.

Aldrich, John H., and Forrest D. Nelson. 1984. Linear Probability, Logit, and Probit Models. Beverly Hills: Sage.

Arthur, Jeffrey B. 1992. The link between business strategy and industrial relations systems in American steel minimills. Industrial and Labor Relations Review 45 (3): 488-506.

1994. Effects of human resource systems on manufacturing performance and turnover. Academy of Management Journal 37(3): 670-87.

Bacon, Nick, Mike Wright, Louise Scholes, and Miguel Meuleman. 2010. Assessing the impact of private equity on industrial relations in Europe. Human Relations 63(9): 1343-70.

Barnard, Chester. 1938. The Functions of the Executive. Cambridge, MA: Harvard University.

Baron, James N., M. Diane Burton, and Michael T. Hannan. 1996. The road taken: Origins and evolution of employment systems in emerging companies. Industrial and Corporate Change 5(2): 239-75.

Baron, James N., Frank R. Dobbin, and P. Devereaux Jennings. 1986. War and peace: The evolution of modern personnel administration in US industry. American Journal of Sociology 92(2): 350-83.

Batt, Rosemary, and Hiroatsu Nohara. 2009. How institutions and business strategies affect wages: A cross-national study of call centers. Industrial E Labor Relations Review 62 (4): 53352.

Beam, Burton T., Jr., and John J. McFadden. 2001. Employee Benefits, 6th ed. Chicago: Dearborn Financial.

Belman, Dale, and Erica L. Groshen. 1998. Is small beautiful for workers? Small Consolation: The Dubious Benefits of Small Business for Job Growth and Wages, pp. 1-60. Washington, DC: Economic Policy Institute.

Birch, David L. 1981. Who creates jobs? Public Interest, No. 65, pp. 3-14. 1987. Job Creation in America: How Our Smallest Companies Put the Most People to Work. New York: Collier-Macmillan.

Bourgeois, L. J., III. 1981. On the measurement of organizational slack. Academy of Management Review 6(1): 29-39.

Brown, Charles, James Hamilton, and James L. Medoff. 1990. Employers Large and Small. Cambridge, MA: Harvard University Press.

Brown, Charles, and James L. Medoff. 2003. Firm age and wages. Journal of Labor Economics 21(3): 677-97.

Bureau of the Census. 2008. Statistics of US Businesses: 2008. Washington, DC: U.S. Department of Commerce.

Bureau of Economic Analysis. 2011. Survey of Current Business, April 2011. Washington, DC: U.S. Department of Commerce.

Bureau of Labor Statistics. 2011. National Compensation Survey: Employee Benefits in the United States, March 2011. Washington, DC: U.S. Department of Labor.

Cardon, Melissa S., and Christopher E. Stevens. 2004. Managing human resources in small organizations: What do we know? Human Resource Management Review 14(3): 295-323.

Carroll, Glenn R., and Michael T. Hannan. 2000. The Demography of Corporations and Industries. Princeton, NJ: Princeton University Press.

Chamberlain, Gary. 1980. Analysis of covariance with qualitative data. Review of Economic Studies 47(1): 225-38.

Clark, Ian. 2009. The private equity business model and associated strategies for HRM: Evidence and implications? International Journal of Human Resource Management 20(10): 203048.

Cochran, William G. 1977. Sampling Techniques. New York: Wiley.

Curran, James, and John Stanworth. 1981. A new look at job satisfaction in the small firm. Human Relations 34(5): 343-65.

Cyert, Richard M., and James G. March. 1963. A Behavioral Theory of the Firm. Englewood Cliffs, NJ: Prentice-Hall. 
Davis, Steven J., John C. Haltiwanger, and Scott Schuh. 1996. Job Creation and Destruction. Cambridge, MA: MIT Press.

Dencker, John C., Marc Gruber, and Sonali K. Shah. 2009. Individual and opportunity factors influencing job creation in new firms. Academy of Management Journal 52(6): 1125-47.

Dennis, William J., Jr. 2000. Wages, health insurance and pension plans: The relationship between employee compensation and small business owner income. Small Business Economics 15(4): 247-63.

DiMaggio, Paul, and Walter W. Powell. 1983. The iron cage revisited: Collective rationality and institutional isomorphism in organizational fields. American Sociological Review 48(2): 147-60.

Doeringer, Peter B., and Michael J. Piore. 1971. Internal Labor Markets and Manpower Analysis. Lexington, MA: Heath.

Edwards, Paul, and Monder Ram. 2010. HRM in small firms: Respecting and regulating informality. In Adrian Wilkinson, Nicolas Bacon, Tom Redman, and Scott Snell (Eds.), The Sage Handbook of Human Resource Management, pp. 524-40. London: Sage.

Fairris, David, and Lee J. Alston. 1994. Wages and the intensity of labor effort: Efficiency wages versus compensating payments. Southern Economic Journal 61 (1): 149-60.

Farhat, Joseph B. 2012. Analyzing complex sample survey data: The case of the Kauffman Firm Survey. Unpublished working paper. Central Connecticut State University.

Goodstein, Jerry D. 1994. Institutional pressures and strategic responsiveness: Employer involvement in work-family issues. Academy of Management Journal 37 (2): 350-82.

Griliches, Zvi. 1969. Capital-skill complementarity. Review of Economics and Statistics 51(4): 465-68.

Guo, Shenyang, and Mark W. Fraser. 2010. Propensity Score Analysis: Statistical Methods and Applications. Thousand Oaks, CA: Sage.

Haltiwanger, John C., Julia I. Lane, and James R. Spletzer. 2007. Wages, productivity, and the dynamic interaction of businesses and workers. Labour Economics 14(3): 575-602.

Haltiwanger, John, Ron Jarmin, and Javier Miranda. 2009. Business Dynamics Statistics Briefing: Jobs Created from Business Start-Ups in the United States. Kansas City, MO: Kauffman Foundation.

2011. Who creates jobs? Small vs. large vs. young. NBER Working Paper No. 16300.

Hamermesh, Daniel S. 1999. Changing inequality in markets for workplace amenities. Quarterly Journal of Economics 114(4): 1085-1123.

Hannan, Michael T., and John Freeman. 1984. Structural inertia and organizational change. American Sociological Review 49: 149-64.

Harrison, Bennett. 1997. Lean and Mean: The Changing Landscape of Corporate Power in the Age of Flexibility. New York: Guilford.

Heckman, James J. 1976. The common structure of statistical models of truncation, sample selection and limited dependent variables and a simple estimator for such models. Annals of Economic and Social Measurement 5: 475-92.

- 1979. Sample selection bias as a specification error. Econometrica 47(1): 153-61.

Heneman, Robert L., Judith W. Tansky, and S. Michael Camp. 2000. Human resource management practices in small and medium-sized enterprises: Unanswered questions and future research perspectives. Entrepreneurship Theory and Practice 25(1): 11.

Herzberg, Frederick. 1968 [2003]. One more time: How do you motivate employees? Harvard Business Review 81(1): 87-96.

Hollister, Matissa N. 2004. Does firm size matter anymore? The new economy and firm size wage effects. American Sociological Review 69(5): 659-76.

Holzer, Harry J., Julia I. Lane, David B. Rosenblum, and Fredrik Andersson. 2011. Where Are All the Good Jobs Going? What National and Local Job Quality Dynamics Mean for US Workers. New York: Russell Sage Foundation.

Hundley, Greg. 2001. Why and when are the self-employed more satisfied with their work? Industrial Relations 40(2): 293-316.

Hunter, Larry W. 2000. What determines job quality in nursing homes? Industrial $\mathcal{E}^{2}$ Labor Relations Review 53(3): 463-481. 
Hunter, Larry W., and John J. Lafkas. 2003. Opening the box: Information technology, work practices, and wages. Industrial E Labor Relations Review 56(2): 224-43.

Hunter, Larry W., Annette Bernhardt, Katherine L. Hughes, and Eva Skuratowicz. 2001. It's not just the ATMs: Technology, firm strategies, jobs, and earnings in retail banking. Industrial Eं Labor Relations Review 54(2): 402-22.

Hurst, Erik, and Benjamin Wild Pugsley. 2011. What do small businesses do? Brookings Papers on Economic Activity, No. 2, pp. 73-142.

Idson, Todd L., and Daniel J. Feaster. 1990. A selectivity model of employer-size wage differentials. Journal of Labor Economics 8(1): 99-122.

Ingram, Paul, and Tal Simons. 1995. Institutional and resource dependence determinants of responsiveness to work-family issues. Academy of Management Journal 38(5): 1466-82.

Jencks, Christopher, Lauri Perman, and Lee Rainwater. 1988. What is a good job?: A new measure of labor-market success. American Journal of Sociology 93(6): 1322-57.

Kaiser Family Foundation. 2011. Employer Health Benefits: 2011 Annual Survey. Washington, DC: KFF

Kalleberg, Arne L. 2011. Good Jobs, Bad Jobs: The Rise of Polarized and Precarious Employment Systems in the United States, 1970s to 2000s. New York: Russell Sage Foundation.

Kalleberg, Arne L., and Mark E. Van Buren. 1996. Is bigger better? Explaining the relationship between organization size and job rewards. American Sociological Review 61(1): 47-66.

Kalleberg, Arne L., Edith Rasell, Naomi Cassirer, Barbara F. Reskin, Ken Hudson, and David Webster. 1997. Nonstandard Work, Substandard Jobs: Flexible Work Arrangements in the US. Washington, DC: Economic Policy Institute.

Kaufman, Bruce E. 1993. The Origins and Evolution of Industrial Relations in the United States. Ithaca, NY: Cornell University Press/ILR Press.

Kimberly, John R. 1976. Organizational size and the structuralist perspective: A review, critique, and proposal. Administrative Science Quarterly 21(4): 571-97.

Knoke, David. 1994. Cui bono? Employee benefits packages. American Behavioral Scientist 37(7): 963-78.

Kochan, Thomas A., and Adam Seth Litwin. 2011. The future of human capital: An employment relations perspective. In Alan Burton-Jones and John-Christopher Spender (Eds.), Oxford Handbook of Human Capital, pp. 647-70. New York: Oxford University Press.

Lazonick, William. 2009. Sustainable Prosperity in the New Economy? Business Organization and High-Tech Employment in the United States. Kalamazoo, MI: Upjohn Institute.

Leicht, Kevin T. 1989. On the estimation of union threat effects. American Sociological Review 54(6): 1035-47.

Lerner, Josh. 2009. Boulevard of Broken Dreams: Why Public Efforts to Boost Entrepreneurship and Venture Capital Have Failed - and What to Do about It. Princeton, NJ: Princeton University Press.

MacDermid, Shelley M., Leon C. Litchfield, and Marcie Pitt-Catsouphes. 1999. Organizational size and work-family issues. Annals of the American Academy of Political and Social Science 562(1): 111-26.

March, James G., and Herbert A. Simon. 1958. Organizations. New York: Wiley.

McGuigan, Kimberly A., Phyllis L. Ellickson, Ron D. Hays, and Robert M. Bell. 1997. Adjusting for attrition in school-based samples: Bias, precision, and cost trade-offs of three methods. Evaluation Review 21 (5): 554-67.

Mellow, Wesley. 1982. Employer size and wages. Review of Economics and Statistics 64(3): 495501.

Meyer, John W., and Brian Rowan. 1977. Institutionalized organizations: Formal structure as myth and ceremony. American Journal of Sociology 83(2): 340-63.

National Federation of Independent Businesses [NFIB]. 2005. Retirement. NFIB Small Business Poll 5(3): 10.

Neumark, David, Brandon Wall, and Junfu Zhang. 2011. Do small businesses create more jobs? New evidence for the United States from the National Establishment Time Series. $R \boldsymbol{c}^{-}$ view of Economics and Statistics 93(1): 16-29.

Nohria, Nitin, and Ranjay Gulati. 1996. Is slack good or bad for innovation? Academy of Management Journal 39(5): 1245-64. 
Oi, Walter Y. 1983. The fixed employment costs of specialized labor. In Jack E. Triplett (Ed.), The Measurement of Labor Cost, pp. 63-122. Chicago: University of Chicago Press.

Oliver, Christine. 1991. Strategic responses to institutional processes. Academy of Management Review 16(1): 145-79.

Osterman, Paul, and Beth Shulman. 2011. Good Jobs America: Making Work Better for Everyone. New York: Russell Sage Foundation.

Pfeffer, Jeffrey. 1978. Organizational Design. Arlington Heights, IL: AHM Publishing.

Pfeffer, Jeffrey, and Huseyin Leblebici. 1973. The effect of competition on some dimensions of organizational structure. Social Forces 52(2): 268-79.

Piore, Michael J. 1973. Notes for a theory of labor market stratification. In Richard C. Edwards, Michael Reich, and David M. Gordon (Eds.), Labor Market Segmentation, pp. 125-50. Lexington, MA: D.C. Heath.

Porter, Michael E. 1980. Competitive Strategy: Techniques for Analyzing Industries and Competitors. New York: Free Press.

Powell, Walter W. 1991. Expanding the scope of institutional analysis. In Walter W. Powell and Paul DiMaggio (Eds.), The New Institutionalism in Organizational Analysis, p. 478. Chicago: University of Chicago Press.

Purcell, Patrick J., and Paul J. Graney. 2002. Retirement plan sponsorship by small employers. Benefits Quarterly 18(1): 25-37.

Rebitzer, James B. 1986. Establishment size and job tenure. Industrial Relations 25(3): 292302.

1993. Radical political economy and the economics of labor markets. Journal of Economic Literature 31 (3): 1394-1434.

Rebitzer, James B., and Lowell J. Taylor. 1995. Efficiency wages and employment rents: The employer-size wage effect in the job market for lawyers. Journal of Labor Economics 13(4): $678-708$.

Reilly, Kevin T. 1995. Human capital and information: The employer size-wage effect. Journal of Human Resources 30(1): 1-18.

Reiss, Peter C. 2011. Descriptive, structural, and experimental empirical methods in marketing research. Marketing Science 30 (6): 950-64.

Robb, Alicia, E. J. Reedy, Janice Ballou, David DesRoches, Frank Potter, and Zhanyun Zhao. 2010. An Overview of the Kauffman Firm Survey: Results from the 2004-2008 Data. Kansas City, MO: Kauffman Foundation.

Rosenbaum, Paul R., and Donald B. Rubin. 1983. The central role of the propensity score in observational studies for causal effects. Biometrika 70(1): 41-55.

Sels, Luc, Sophie De Winne, Jeroen Delmotte, Johan Maes, Dries Faems, and Anneleen Forrier. 2006a. Linking HRM and small business performance: An examination of the impact of HRM intensity on the productivity and financial performance of small businesses. Small Business Economics 26(1): 83-101.

Sels, Luc, Sophie De Winne, Johan Maes, Jeroen Delmotte, Dries Faems, and Anneleen Forrier. 2006b. Unraveling the HRM-performance link: Value-creating and cost-increasing effects of small business HRM. Journal of Management Studies 43(2): 319-42.

Shane, Scott. 2003. A General Theory of Entrepreneurship: The Individual-Opportunity Nexus. Northampton, MA: Edward Elgar.

Sharfman, Mark P., Gerrit Wolf, Richard B. Chase, and David A. Tansik. 1988. Antecedents of organizational slack. Academy of Management Review 13(4): 601-14.

Singer, Judith D., and John B. Willett. 2003. Applied Longitudinal Data Analysis: Modeling Change and Event Occurrence. New York: Oxford University Press.

Singh, Jitendra V. 1986. Performance, slack, and risk taking in organizational decision making. Academy of Management Journal 29(3): 562-85.

Skrondal, Anders, and Sophia Rabe-Hesketh. 2004. Generalized Latent Variable Modeling: Multilevel, Longitudinal, and Structural Equation Models. Boca Raton: Chapman and Hall/CRC.

Slichter, Sumner H., James Joseph Healy, and E. Robert Livernash. 1960. The Impact of Collective Bargaining on Management. Washington, DC: Brookings Institution.

Smith, Adam. 1776. [1982]. An Inquiry into the Nature and Causes of the Wealth of Nations. Indianapolis: Liberty Press.

Smith, Sheryl Winston. 2012. New firm financing and performance. In Douglas Cumming 
(Ed.), Oxford Handbook of Entrepreneurial Finance, pp. 133-50. New York: Oxford University Press.

Stangler, Dane, and Robert E. Litan. 2009. Where Will the Jobs Come From? Kansas City, MO: Kauffman Foundation.

Stinchcombe, Arthur L. 1965. Social structure and organizations. In James G. March (Ed.), Handbook of Organizations, pp. 143-93. Chicago: Rand McNally.

Tan, Justin, and Mike W. Peng. 2003. Organizational slack and firm performance during economic transitions: Two studies from an emerging economy. Strategic Management Journal 24(13): 1249-63.

Thompson, James D. 1967. Organizations in Action: Social Science Bases of Administrative Theory. New York: McGraw-Hill.

Tsai, Chin-Ju, Sukanya Sengupta, and Paul Edwards. 2007. When and why is small beautiful? The experience of work in the small firm. Human Relations 60(12): 1779-1807.

Voss, Glenn B., Deepak Sirdeshmukh, and Zannie Giraud Voss. 2008. The effects of slack resources and environmental threat on product exploration and exploitation. Academy of Management Journal 51(1): 147-64.

Welsh, John A., and Jerry F. White. 1981. A small business is not a little big business. Harvard Business Review 59(4): 18-27.

Western, Bruce, and Jake Rosenfeld. 2011. Unions, norms, and the rise in US wage inequality. American Sociological Review 76(4): 513-37.

Wever, Kirsten. 1995. Negotiating Competitiveness. Cambridge, MA: Harvard Business School.

Wholey, Douglas R., and Jack W. Brittain. 1986. Organizational ecology: Findings and implications. Academy of Management Review 11(3): 513-33.

Wooldridge, Jeffrey M. 2010. Econometric Analysis of Cross-Section and Panel Data, 2nd ed. Cambridge, MA: MIT Press. 